\title{
The Mechanics of Initiation and Development of Thrust Ramps
}

\author{
Sarah S. Wigginton ${ }^{1,2}$ \\ Elizabeth S. Petrie ${ }^{3}$ \\ James P. Evans ${ }^{1}$ \\ ${ }^{1}$ Department of Geosciences, Utah State University, 4505 Old Main Hill, Logan, UT 84322-4505 \\ james.evans@usu.edu \\ ${ }^{2}$ INTERA Inc, 3240 Richardson Road, Suite 2, Richland, Washington 99354 \\ sarahwigginton92@gmail.com \\ ${ }^{3}$ Department of Natural and Environmental Sciences, Western Colorado University, Gunnison, CO 81231 \\ espetrie@western.edu
}

The paper is a non-peer reviewed preprint submitted to EarthArXiv. Subsequent versions of this paper may differ, as the paper is intended to be submitted to Mountain Geologist. We welcome feedback on the paper via email to the authors. 


\begin{abstract}
We examine the mechanics of thrust fault initiation and development in sedimentary rocks which accounts for vertical variation in mechanical strength of the rocks. We use numerical mechanical models of mechanically layered rocks to examine thrust ramp nucleation in competent units, and fault propagation upward and downward into weaker units forming folds at both fault tips. We investigate the effects of mechanical stratigraphy on stress heterogeneity, rupture direction, fold formation, and fault geometry motivated by the geometry of the Ketobe Knob thrust fault in central Utah. The study incorporates finite element models to examine how mechanical stratigraphy, loading conditions, and fault configurations determine temporal and spatial variation in stress and strain. We model the predicted deformation and stress distributions in four model domains: (1) an intact, mechanically stratified rock sequence, (2) a mechanically stratified section with a range of interlayer frictional strengths, and two faulted models, (3) one with a stress boundary condition, and (4) one with a displacement boundary condition. The models show that a dramatic increase in stress develops in the competent rock layers whereas the stresses are lower in the weaker rocks. The frictional models reveal that the heterogeneous stress variations increase contact frictional strength. Faulted models contain a $20^{\circ}$ dipping fault in the most competent unit. The models show an increase in stress in areas above and below fault tips, with extremely high stresses predicted in a 'back thrust' location at the lower fault tip. These findings support the hypothesis that thrust faults and associated folds at the Ketobe Knob developed in accordance with the rampfirst kinematic model and development of structures was significantly influenced by the nature of the mechanical stratigraphy.
\end{abstract}

\title{
INTRODUCTION
}

The geometrical relationships and kinematic models used to explain the formation of structures in fold and thrust belts (Dahlstrom, 1970; Boyer and Elliott, 1982; Butler, 1982; Suppe, 1983; Cooper and Trayner, 1986; Suppe and Medwedeff, 1990) support a classic flat-ramp kinematic model of thrust fault propagation (Suppe and Medwedeff, 1990). The flat-ramp model is based on a thrust fault that nucleates on a weak, shallowly dipping décollement horizon and propagates along the décollement until the resistance to frictional slip on the flat is greater than resistance to brittle failure in rocks above the décollement. At this point faults propagate upward to form a ramp (Rich, 1934; Rodgers, 1950; Dahlstrom, 1970; Boyer and Elliott, 1982; Butler, 1982, Williams and Chapman, 1983; Mitra, 1990; McClay, 2011).

While this geometric/kinematic model is well documented in fold-and-thrust belts, it may not fully account for the mechanics and mechanisms by which thrust fault formation occurs. Integrating rock material properties and mechanical models with traditional field geology and kinematic models allows for investigations of different models for the development of thrust faults and folds (Chapple, 1970; Erickson, 1996; Underwood et al., 2003; Teixell and Koyi, 2003; Bourne, 2003; Roche et al., 2013; Hughes et al., 2014; Hughes and Shaw, 
2015). Merging mechanics with kinematic models can help answer questions about the conditions that promote failure at thrust ramps, how stress state variations may promote failure, and the rock properties govern the continued propagation or arrest of newly formed thrust faults (Busetti and Fang, 2018).

The mechanical stratigraphy of rocks in some thrust terrains may exert a control on nascent thrust fault formation (Eisenstadt and De Paor, 1987; Ferrill et al., 2017). Stress concentrations may form at imperfections in mechanically strong layers and stress heterogeneities at these sites in the stratigraphic system may cause faults to nucleate on the ramp and arrest in mechanically weak layers above and below (Eisenstadt and De Paor, 1987; Roche et al., 2013; Ferrill et al., 2016). Field evidence of this "ramp-first" faulting style is documented in mechanically layered formations at the sub-meter scale (Figure 1; Eisenstadt and De Paor, 1987; McConnell et al., 1997; Ferrill et al., 2016) and at the map scale (Onderdonk et al., 2005). Primary indicators of the ramp-first faulting style include fault propagation folds occurring at both fault tips and a displacement profile that is largest in the center and decreases toward both fault tips (Ferrill et al., 2016). These observations indicate that mechanical stratigraphy exerts an influence on the nucleation, propagation, and arrest of developing thrust faults is needed to describe the loading conditions that promote failure.

We integrate field-based structural analysis and two-dimensional cross section reconstructions (Wigginton, 2018), with the results of mechanical finite element models presented here to investigate the effects of mechanical stratigraphy on stress heterogeneity, rupture direction, and thrust fault geometry. We use the results of field-based studies (Petrie et al., 2018; Wigginton, 2018.) and their resulting kinematic models are the foundation for finite element mechanical models of small-displacement thrust fault development in rocks with that contrast in mechanical strength and fault propagation folds in the hanging wall and footwall.

\section{Background}

Mechanical stratigraphy is the stratal expression of the contrasts in the cohesive, compressive, tensile, and frictional strengths of rock, along with the thicknesses of rock units (Corbett et al., 1987; Gross et al., 1995; Underwood et al., 2003; Laubach et al., 2009; Ferrill et al., 2017). Mechanical stratigraphy affects fault nucleation and propagation (Teixell and Koyi, 2003; Underwood et al., 2003; Laubach et al., 2009; Roche et al., 2013; Ferrill et al., 2017), fracture nucleation location (Eisenstadt and De Paor, 1987; Ferrill et al., 2017), fault length, width, and the aperture across a slip surface (Laubach et al., 2009; McGinnis et al., 2017), fault-growth directions (King et al., 1988; Mitra and Mount, 1998), the proportions of folds and faults that form (Morley, 1994; Erickson, 1996), fold geometry (Fischer and Jackson, 1999; Gutiérrez-Alonso and Gross, 1999), fault-fold interactions (Chester, 2003), and faults shape (Woodward and Rutherford, 1989; Pfiffner, 1993; Ferrill and Morris, 2008). Strong or competent units withstand higher stresses before deforming plastically (permanently) and they accommodate stress loads by brittle failure (Currie et al., 1962). Conversely, weak or incompetent strata deform plastically at lower stresses and may deform ductily before fracturing in response to increased stress (Goodman, 1980). As a result, stress applied to a mechanically layered section with different Young's 
moduli might lead to varying layer-parallel stresses within the anisotropic package (Roche et al., 2013). The highest stresses are expected to form in the competent units, and this is where faulting might initiate in some mechanically layered package (Eisenstadt and De Paor, 1987; Ferrill et al., 2016). This contrast in deformation styles between competent and incompetent rocks creates strong stress heterogeneity in mechanically layered systems.

The ramp-first fault model accounts for the impact of mechanically layered stratigraphy on thrust fault formation (Figure 1). The influence of mechanically stratified formations requires models of thrust fault propagation wherein: 1) faults nucleate in structurally strong (stiff, low ductility) layers (i.e. brittle failure occurs), 2) they can propagate upward and downward, and 3) fault ramps form before the flats (Figure 1; Chapman and Williams, 1985; Eisenstadt and De Paor, 1987; Ramsay, 1992; Tavani et al., 2006; Uzkeda et al., 2010; Ferrill et al., 2016).

Primary lines of evidence of the ramp-first style include the development of fault propagation folds (Williams and Chapman, 1983; Woodward, 1986, discussed in Fischer et al., 1992; Eisenstadt and De Paor, 1987; Ramsay, 1992; Schmidt et al., 1993; Morley, 1994; McConnell et al., 1997; Welch et al., 2009; Uzkeda et al., 2010; Ferrill et al., 2016), and the slip distribution patterns along faults (McConnell et al., 1997; Ferrill et al., 2016; Marshak et al., 2019). If a fault nucleates in a competent layer and propagates upward and downward, it is predicted to arrest in fault-tip folds in the more ductile layers above and below (Figure 1). These asymmetric folds verge in the transport direction of the thrust fault. The dual-directional propagation of a thrust fault creates a hanging wall anticline associated with the upward propagating tip and a footwall syncline associated with the downward propagating fault tip (Figure 1). Fault slip patterns along a "ramp-first" fault slip decreases up- and down-dip along faults (Ellis and Dunlap, 1988; McConnell et al., 1997; Apotria and Wilkerson, 2002; Tavani et al., 2006; Cawood and Bond, 2020). All these features point to a potential influence of mechanical stratigraphy on the location, geometry, and direction of thrust faults development.

Previous models of the mechanics of thrust fault nucleation and fold formation used elastic dislocation models (Rodgers and Rizer, 1981), wax analogue models (Odonne, 1990), two-dimensional (2D) numerical models (Reches and Eidelman, 1995), 2D numerical models of viscous flow around a fault (Grasemann et al., 2003), 2D finite element models of elasto-plastic deformation (Strayer and Hudleston, 1997), displacement field analysis (Grasemann et al., 2005), and three-dimensional (3D) elastic numerical models (Roche et al., 2013). These studies produced a number of findings which bolster the ramp-first model of thrust fault propagation: 1) Odonne (1990) and Grasemann et al. (2005) found that displacement along the fault causes heterogeneous re-orientation of the strain axes and the highest strains were found at the fault tips (Reches and Eidelman, 1995). Here the increased stresses were responsible for the development of fault- propagation folds, and the kinematic model of McConnell et al. (1997) for a dual edged fault propagation fold model is an excellent explanation of their results. 2) Models confined with overburden pressure produce significantly more stress heterogeneity around the fault and the degree of fault related folding likely depends partly on the depth of the 
fault (Odonne, 1990). 3) Low-angle faults, (dips $\sim 30^{\circ}$ ), are more likely to produce the fault propagation fold geometry (Grasemann et al., 2003; Grasemann et al., 2005). 4) The stress conditions that create fault propagation folds are largely insensitive to the rheology of the rock (as long as the rheology is continuous and uniform), so fault propagation folds can form in any rock type (Reches and Eidelman 1995; Grasemann et al., 2005). 5) Relatively small differences in yield strengths can make a significant change to the sequence of failure in a sedimentary package (Roche et al., 2013). Roche (2013) showed that for stratigraphic sequences with little variation in strength, nucleation occurs in the stiff layers (limestone or sandstone), while failure occurs in the compliant layer (claystone) if the stiff layer has high cohesion (Roche et al., 2013).

\section{METHODS}

A field exposure of a thrust ramp in central Utah motivated this study of thrust fault ramp formation. The Ketobe Knob thrust cuts through the Jurassic Entrada and Curtis Formations (Neuhauser et al., 1988; Wacker, 2001) (Figures 2, 3, 4a). We briefly summarize the key geologic relationships of the thrust and related structures, including a kinematic restoration of the structure (Wigginton, 2018). These results also provide kinematic evidence for maximum displacement in the stronger stratigraphic units, and document the presence of a footwall syncline.

We use the numerical finite element modeling program ABAQUS ${ }^{\mathrm{Tm}}$ (Dassault Systèmes, 2011) to mechanically model fault-fold structures. This finite element code allows for the creation of complex geometries, including non-planar faults and mechanical stratigraphy to be combined with material properties (Smart et al., 2012). The program satisfies the equilibrium, constitutive, and compatibility relationships necessary to create a mechanically plausible model. We establish the initial boundary conditions, stress state, and constitutive relationships, consider a range of material properties to simulate rock behavior (simple elastic or elastic-plastic responses) and examine variable friction between layers (Smart et al., 2012; Petrie and Evans, 2016). Parameterization studies were performed using a simple 3 layer model with a coarse mesh to test the impact of rock properties, interlayer slip, overburden pressure, fault friction, and fault angle individually. The preliminary models enable us to decide on reasonable input values such as the use of damping factors, nonlinear algorithms, and surface contact types (Smart et al., 2012; 2014). We then examine specific mechanical models with realistic stratigraphy and finer meshes in order to explore a range of questions, track the spatial and temporal distributions of magnitudes and orientations of stresses as well as elastic and inelastic strains throughout the model domain (Petrie and Evans, 2016; Smart et al., 2010, 2012). The FEMs have a rigid boundary condition at the base to prevent downward movement and a rigid boundary condition at the top to represent overburden material and to prevent excess distortion of the topmost layer (upward movement restricted). These models do not incorporate pore pressure in the material properties. 
The models consist of two load steps. In step 1 we apply a downward gravitational acceleration to the model and let it equilibrate. The gravity load applied in step 1 remains on the model through step 2. In step 2 we apply the horizontal tectonic loads. The downward pressure load simulates an overburden of $40 \mathrm{MPa}$ as suggested from the stress inversions of small fault slip data for the site. A horizontal load of $200 \mathrm{MPa}$ is applied, which is more than sufficient to induce failure of all rock units in the model. Models were run with a range of mesh sizes and time increments to assure we had achieved a convergent result - that is we test to make sure that alteration of the time increment, and mesh size did not alter the distribution of stress and strain in the final model. We ran models with the same parameters while we incrementally reduced the mesh size from $2 \mathrm{~m}$ to $0.5 \mathrm{~m}$ and altered the run time from $1 \mathrm{~s}$ to $10 \mathrm{~s}$. Each model yielded the same pattern of stresses and very close to the same magnitude.

\section{RESULTS}

\section{Geologic Analyses}

The Ketobe Knob thrust exposure is a lateral ramp in the southwestern part of the Buckhorn Flats thrust complex, Utah (Figures 2 and 3, Petrie et al., 2018 ) where moderate-displacement thrusts cut the Jurassic Entrada Formation through the Curtis Sandstone (Figure 3). Rocks at the Ketobe Knob outcrop can be divided into 5 mechanical units (Figure 4; Table 1) based on the distribution of mesoscopic structures, mineralogic and sedimentary petrographic analyses, and Schmidt rebound hammer field tests (Wigginton, 2018). This mechanical stratigraphy is related to, but may differ from, formally stratigraphic units. Relative rock strengths were determined in the field with an N-type Schmidt rebound hammer. Rebound was used with the following relationships to estimate UCS and E values:

$$
\begin{aligned}
& \ln (\mathrm{UCS})=0.792+0.067 \mathrm{R} \\
& \ln (\mathrm{E})=-0.967+3.091 \ln (\mathrm{R})
\end{aligned}
$$

where $\mathrm{R}=$ measured rebound value, $\mathrm{E}=$ Young's Modulus, and UCS is the uniaxial compressive (Aydin and Basu, 2005; Katz et al., 2000) (Table 1). The strongest units in the section are the sandstone-rich parts of the Entrada Formation, with E values of 17 to $22 \mathrm{GPa}$, and UCS values of 47-62 GPa, whereas the earthy Entrada, and the Curtis Formation rocks have values that are half these values (Table 1; Figure 4). This meter-scale variation in elastic properties is consistent with the analyses of Petrie et al. (2012); Petrie and Evans 2016 and these variations affect the brittle failure response of a layered sequence in a range of settings (Underwood and Cooke, 2003; Petrie et al., 2014).

Wigginton (2018) explored three types of kinematics models with Move ${ }^{\mathrm{TM}}$ to examine balanced fault reconstructions of the Ketobe Thrust. Within these three classes different variations of structural timing was explored and tested for acceptability by their area balance and logic of restorability. The preferred area-balanced restoration (Figure 5) consists of a thrust fault that nucleates in the sandstone member of the Entrada 
Formation and propagates upward and downward into the weaker rocks (made weaker due to laminations, less calcite cementation, or overall unit thickness). The displacement-distance profile or displacement-distance diagram (Figure 6) shows the likely region of fault nucleation could be the site with the greatest displacement (Muraoka and Kamata,1983; Williams and Chapman, 1983; Ellis and Dunlap, 1988). The lower fault shows the maximum displacement somewhere near the boundary of the upper Entrada sandstone, and it loses displacement toward the upper and lower fault tips. This suggests that the fault nucleated somewhere in the upper Entrada sandstone. Lastly, the upper fault shows a maximum displacement in the upper Entrada sandstone with less offset toward both fault tips. This profile suggests that the upper fault propagated upward and downward (Figure 6).

Based on the preferred restoration we conclude that: (1) both major faults nucleated in mechanically strong upper Entrada sandstone, (2) the upper and lower faults propagated upwards and downwards as shown by the decrease in displacement toward the upper and lower fault tips, and (3) the hanging wall anticline and footwall syncline formed in mechanically weaker layers and were created by upward and downward fault propagation. While it is a non-unique solution, the successful reconstruction in Move ${ }^{\mathrm{TM}}$ supports a kinematic model in which the faults nucleate in structurally strong layers, propagate upwards and downwards, and create folds in more ductile stratigraphic units.

\section{Mechanical Modeling}

The finite element models (FEMs) of mechanically layered sequences in ABAQUSTM explore the rampfirst style of thrust fault propagation. The FEMs incorporate field data and provide a mechanically-based analysis of the development of the thrust faults at the Ketobe Knob site. We examine models for intact, unfaulted layered sequences with and without frictional interlayer slip (Figure 7a), and models of a faulted layered sequence without and with variations of mechanical properties of the rock (Figure 7b).

\section{Model Inputs}

Field work conducted at the Ketobe Knob site serves as the guide for the number of layers to include in the model, their thicknesses, compressive strengths, initial stress state of the model (Table 2), and the nature of inter-layer slip. We use elastic-plastic (Mohr-Coulomb) material properties to describe the bulk deformation of upper crustal rocks (Smart et al., 2012), and we use a Coulomb friction model to govern slip between layers and faulted surfaces (Smart et al., 2010).

We created two model suites within this framework: 1) intact and unfaulted models to examine how the difference in mechanical stratigraphy affects the distribution of stresses in the pre-faulted state, and 2) faulted models which use the same inputs but contain a planar fault to show how a recently nucleated fault alters stress in the surrounding rocks. The faulted models were run with slight variations including a) variation 
in mechanical stratigraphy, b) no variation and mechanical stratigraphy, and c) variation in mechanical stratigraphy and deformed by a horizontal displacement load.

\section{Unfaulted Models}

The intact and unfaulted models examine the base case for the distribution of stresses and strains in an intact stratigraphic sequence. We apply horizontal far-field tectonic stresses to the stratigraphy and show how the difference in mechanical strength of each unit at the Ketobe Knob affects the distribution of stresses. We test the hypothesis that stronger units experience higher stress than weaker units, and test the hypothesis that failure might occur first in the strong horizons due to stress concentrations there instead of in the weak layers.

The unfaulted models reveal the dramatic variation of stresses in different lithologies of the stratigraphic section (Figure 8a, Appendix B). The stresses in the stratigraphic column range from $\sim 130 \mathrm{MPa}$, $70 \mathrm{MPa}$ below the boundary load condition, in the weaker Curtis sandstone, Curtis conglomerate, and Earthy Entrada silty member, and up to $\sim 300 \mathrm{MPa}$ in the Entrada sandstone (Figure 8c). Animations of the model run show the stresses are consistently higher in the strong units and radiate outward through the weaker units. The largest contrast in layer strength is at the center of the model through time, and stress contrasts are evidence layer interfaces (Figure 8c). Maximum principal stress axes are deflected downward in the Curtis Sandstone (Figure 8b). Linear stress through time behavior (Figure 9a) shows the higher stresses in strong units (Entrada sandstone) start at the earliest time steps and the weaker units experience lower stresses for each increment of strain, whereas the two strongest units (Table 1) are more resistant to deformation (i.e. for a given strain, stress is higher in the strong rock units; Figure 8c). Stress-strain and stress-time curves (Figure 9a and 9b) shows that the weaker units depart from linear elastic behavior earlier than in the strong layer, and that ductile deformation continues through the model run.

Influence of Interlayer Slip Slickensides on bedding surfaces at the Ketobe Knob site indicate that interlayer frictional slip occurred during deformation throughout the area (Wigginton, 2018). In ABAQUS we examine models where the coefficient of friction at layer interfaces varies from $\mu=0.0$ to 0.85 . In the frictionless end member the layers freely slide past each other and stress magnitudes remain uniformly low through the sequence (Figure 10a). Strain profiles (Figure 10e) for this case shows that the free slip allows each layer to shorten independently and slip at their tops and bases (Figure 10e). For the intermediate values of $\mu$, the stresses are consistently higher in the strong units and radiate outward through the weaker units. As the values of the interlayer friction coefficients increase, the rock sequences exhibit reduced stresses in the Curtis sandstone (Figure 10), and significant increases in the stronger Entrada Sandstone. The strains are more uniformly distributed, whereas the stress distribution is heterogeneous (Figures 10b-10d). The stresses in the stratigraphic 
section range from $\sim 130 \mathrm{MPa}$ to $\sim 300 \mathrm{MPa}$. With $\mu$ of 0.85 , the stresses in the stronger layers expand laterally, and are communicated broadly to the overlying layer (Figure 10d).

The stress-time curves (Figure 9) for these models may provide significant insights into the behavior of the sequence. In the stress-time behavior for $\mu=0$ model, stresses in the strongest layer increase with time while all the other layers have similar, nearly linear stress-time behaviors. Towards the end of the experiment, stresses in the strong layer decrease, and the layer directly below exhibits an increase in stress, until at the end of the model run, all layers equilibrate to the same stress. Since each layer can respond independently during the model run, they develop their own strain behavior. As there is no bond strength with its overlying neighbors, the strongest layer does not effectively communicate any excess stress to the adjacent overlying layer. Some stresses are transferred to the lower layer, perhaps because the vertical loads are higher here. For any level of frictional strength between the layers, at the end of the model run stresses are concentrated in the strong horizon and some of these stresses are transmitted to the adjacent rocks.

\section{Faulted Models}

Due to the complexities in generating true shear fractures under compression in most finite element models (Hedayat et al., 2015; Zhuang et al., 2015; Sivakumar and Maji, 2016) we place a $20^{\circ}$ dipping fault as a seed in the unfaulted Entrada Sandstone where stresses in the unfaulted model are highest (Figure 11). The fault then forms a boundary along which mesh elements are defined in the model. We examine models in which: a) variations in mechanical stratigraphy and deformed by a stress boundary condition load, b) no variation in mechanical stratigraphy and deformed by a stress boundary condition, and c) variation in mechanical stratigraphy deformed by a displacement boundary condition. The model parameters for the faulted models are the same as for the unfaulted models (Tables 3 and 4).

Faulted Models Without Variation in Mechanical Stratigraphy The model of a newly formed thrust fault in uniform stratigraphy serves as the base case for the faulted models and shows the distribution and concentrations of stresses created by a newly formed fault without the additional impact of mechanically layered stratigraphy. All the model inputs remain the same as the previous model, except that we assign uniform material properties (those of the upper Entrada sandstone) to represent a layered, uniform package of sedimentary rocks (Figure 12).

Both fault tips show Coulomb stress perturbations with a slight stress increase in the compressional quadrants, with a very focused stress increase at the footwall of the upper fault tip, followed by decreases in stress in the dilatational quadrants (Figure 12). The hanging wall above the upper fault tip and lower fault tips both show an increase in stress and heterogeneous reorientation of stress axes around the fault tips (Figure 12b). The region of increased stress below the lower fault tip is larger than the area of increased stress above 
the upper fault tip (Figure 12). A stress increase is also indicated slightly above and below the fault tips in the adjacent stratigraphy. This result shows that without the added effect of mechanical stratigraphy, nascent thrust faults may result in an increase in stresses near the faults tips and this induces deformation in the hanging wall and footwall near the fault tips. Stresses are slightly larger in the strongest units throughout the simulation.

Faulted Models with Variation in Mechanical Stratigraphy The faulted model with variation in mechanical stratigraphy, based on lithology at the Ketobe Knob, shows an extreme concentration of stresses at the fault tips and in the footwall and hanging wall wedges (Figures 12 and 13). High stresses form in the hanging wall and footwall wedges first, then radiate outward through the rest of the model..

The stresses are also consistently elevated in the units above (Curtis Conglomerate) and below (earthy Entrada Sandstone) the fault tips. Stresses in the stratigraphic units above and below the strong layers are significantly lower. There is a larger increase of stress in the footwall than in the hanging wall. Cumulative strain is extremely high in the Curtis conglomerate and earthy Entrada sandstone directly adjacent to the fault tips (Figure 13). The patterns of elevated strain so the same vengeance directions of the folds at the Ketobe Knob outcrop; the strain pattern for the hanging wall anticline verges to the right, and the strain pattern for the footwall syncline verges to the left.

\section{Faulted Model with Variation in Mechanical Stratigraphy and a Displacement Boundary Condition}

The displacement model simulates a rapid load scenario (Smart et al., 2010, 2012). This model shows the perturbed stress state directly after the loading event (Figure 13). The displacement boundary condition necessitates additional material be added to the edges of the model to absorb material failure directly adjacent to the applied load. We add a thick base layer for the upper units to slide over to avoid edge effects of the lower boundary condition. The displacement load model parameters (Table 4) have an initial static stress state to create a pre-stressed volume of rock in a contractional stress regime. The gravitational load is applied in step 1. In step 2 an additional boundary condition is placed on the right side of the model to prevent movement in the $\mathrm{x}$ direction, then a horizontal displacement of $2 \mathrm{~m}$ was applied to the left side (Figure 13a). The displacement models use the same material properties as previous versions except for the interlayer slip and fault coefficient of friction (Table 4). We applied a friction coefficient of $\mu=0.2$ to allow interlayer slip and prevent the layers from failing where the load was applied.

Faulted models deformed by the displacement boundary condition facilitate more deformation in the form of folds and result in significant stress concentrations and principal stress reorientations at fault tips (Figure 13). We apply $2 \mathrm{~m}$ of horizontal displacement to the hanging wall. The results show the units above and below the fault are deformed into fault propagation folds (Figure 13). A hanging wall anticline in the Curtis conglomerate and a footwall syncline in the earthy Entrada silty sandstone developed. The hanging wall anticline verges to the right and the footwall syncline verges to the left. The footwall syncline (5.5 m amplitude) is larger than the hanging wall anticline ( $2.7 \mathrm{~m}$ amplitude). This difference in amplitude size could be due to the difference in bed thickness between the Curtis conglomerate and the earthy Entrada sandstone, a difference 
in material properties, or an increase in overburden pressure at the lower fault tip (Figure 14). While the amplitudes are not the same as the folds seen in the field, it is easy to imagine that this model is an early snapshot in the formation history of the present-day structures at the Ketobe Knob. Animations of the model show simultaneous formation of the hanging wall anticline and footwall syncline as displacement increases on the fault. The distribution of stresses in the model also indicates that the formation of a back-thrust in the Curtis sandstone (Figure 13b). The stress pattern shows a thin band of increased stress at $\sim 40^{\circ}$. High stress concentrations on the left side of the model should be disregarded as they are a result of rock failure at the location of load application. The distribution of stresses in each unit through time mirrors results from the unfaulted model before they level off later in the loading step (Figure 9d). Stresses are highest in the Entrada sandstone units and lower in the Curtis Formation and the earthy Entrada, as seen in all previous models.

The extreme stress concentration at the hanging wall side of the lower fault tip (Figure 13d) exhibits the geometry of a back thrust at the lower fault bend. Principal stress orientations are significantly reoriented here. These orientations indicate that steeply dipping faults would form at the lower tip zones of the faults (see also Strayer and Hudleston, 1997).

\section{DISCUSSION}

The results of the finite element models examine how the mechanical stratigraphy of the faulted rocks influences thrust fault nucleation and propagation, and we examined the ramp-first model for thrust fault development (Eisenstadt and De Paor, 1987; Ferrill et al., 2016). We discuss the nature of the fault-to-fold transitions, the nature of mechanical stratigraphy and its influence on the structure, and details of the fault development.

\section{Mechanical Stratigraphy}

A number of factors contribute to determining the material response of layered rocks to stresses. Rock composition may significantly- affect failure properties, but there are few universal relationships solely between lithology and rock strength in many clastic sedimentary rocks (Busetti and Fang, 2018). Instead, lithology, combined with layer thicknesses, grain size, grain composition, laminae, degree and nature of cementation and other factors affect rock strength and failure modes in these types of rocks (Corbett et al., 1987; Petrie et al., 2015; Busetti and Fang, 2018).

The numerical modeling results (Figures 10-13) show that the stress magnitudes are significantly perturbed from the uniform starting stresses in all models. Peak predicted stresses are larger in the stronger horizons, whereas the weaker units have much lower stresses. The models show that the uniform stress state at the beginning of the model runs quickly deviate to nonuniform distributions. We also show how to use experimentally determined rock mechanics properties for the rocks exposed at Ketobe Knob in conjunction 
with basic Mohr-Coulomb failure analysis to show how failure might first occur in these stronger horizons (Petrie et al., 2015). Experimentally determined values for the cohesive strengths and tensile strengths of similar rocks (Petrie et al., 2014; Petrie et al., 2015) provide general constraints on the Coulomb failure envelopes in these rocks. The relatively strong Entrada Sandstone sequences tend to have lower tensile and higher cohesive strengths than the slit-rich rocks, and for the differential stresses predicted in these models, we see that the Entrada Sandstones may reach failure (Figure 14), whereas the low stresses in the weaker rocks, combined with slightly higher tensile strengths, show that these rocks may not yet be at failure (Figure 14). While the yield strengths of the weak rocks are lower, the stresses in the weak rocks are also significantly reduced (as the strong rocks act as load bearing sequence). This stress imbalance and strength difference within the mechanically layered stratigraphic section reverse the anticipated order of rock failure.

The strength contrast between units affects fracture propagation (Petrie, 2014). Two rock units with similar strengths are likely to have a fracture propagate through the interface. Conversely, strong layer contrasts (a weak unit next to a strong unit) are likely to arrest propagating fractures (Cooke and Underwood, 2001; Larsen et al., 2010). This relationship is demonstrated by the fault and fold formation at the Ketobe Knob where faults likely nucleated in stiff units, then formed fault propagation folds in more ductile units before they broke through.

\section{Mechanics of Thrust Fault Development}

The finite element models provide a mechanical explanation for the field observations and reconstructions of the thrust fault-fold relationships (Ferrill et al, 2017; Wigginton, 2018). The results from the faulted models show that initially uniform stresses in the sedimentary rocks quickly evolve to a non-uniform distribution with high stresses concentrated in the strong layers. In the faulted models then stress transfers to the fault tips into the upper and lower weaker layers (Eisenstadt and De Paor, 1987), and conjugate stresses form from the lower fault tip. Fault-propagation folds form and the faulted models show an increase in stress and strain in the unfaulted units around the fault tips (in the Curtis conglomerate and the Earthy Entrada). This increase in stress occurred in the models without variation in mechanical stratigraphy and are even more dramatic in the models with variation in mechanical stratigraphy (stress in the strong layers is more than twice the stress in the weak layers). The results also explain macroscale footwall folding that is so common; the stress and strain heterogeneities are present at both the upper and lower fault tips regardless of the direction of propagation or the mechanical stratigraphy.

Deformation in the hanging wall of the thrust is also suggested by the development of a high stress region in the hanging wall of the thrust, near its fault tip, and dipping towards the fault (Figure 15a). The stress patterns are similar to the back thrust development predicted from rock models (Serra, 1977; Chester et al. 1991; Marshak et al., 2019), numerical models (Berger and Johnson, 1982) and field studies. Our results also 
suggest that high back thrust stresses develop early in the junction of the fault tip and the lower, weaker rock contact, consistent with analog models of frontal thrust development (Marshak et al., 2019).

\section{Fold Geometry}

The Ketobe Knob thrust faults and associated hanging wall anticlines and footwall synclines reveal fault/fold geometries that are compatible with the ramp-first style of thrust fault formation. The presence of macroscale footwall deformation at the Ketobe Knob (Wigginton 2018; Petrie et al.et al., 2018) and in other studies (McConnell et al, 1997; Ferrill et al., 2017) favors ramp-first formation over flat-ramp formation. The Ketobe Knob thrust shape and position of the folds is consistent with that expected from fault propagation folds, i.e. when the fault propagates through the fault tip folds it leaves behind tight, steep to overturned anticlines and synclines adjacent to the fault surface (Suppe and Medwedeff, 1990). The elevated stress and heterogeneous reorientation of stress axes at the upper and lower fault tips in faulted models agree with analogue and analytical models (Rodgers and Rizer,1981; Patton and Fletcher, 1995). The region of potential failure, primarily folding. lies directly above a reverse-fault is elongated parallel to the dip of the fault (Patton and Fletcher, 1995). Rodgers and Rizer (1981) found shear stress to be the greatest at the fault tip and vertical displacement increased above the fault tip. These results and our results enforce that we should expect elevated stresses that create the potential for fault propagation folds at all fault tips, regardless of lithology or propagation direction.

The folded Curtis conglomerate and Earthy Entrada silty sandstone exhibit thinner beds than the other units. The Curtis conglomerate is only $1.6 \mathrm{~m}$ thick and the Earthy Entrada unit is $2.9 \mathrm{~m}$ thick but shows extremely fine laminations ( $0.25 \mathrm{~mm}$ in thin section). The Curtis sandstone, while weaker in terms of elastic strength (low rebound) is very thickly bedded, which explains its lack of folds in the hanging wall. The upper and lower Entrada sandstones are elastically strong (high rebound) and are thickly bedded, which would make them the most competent units in the stratigraphic section.

The sizable amplitude difference between the hanging wall anticline and footwall syncline could be due to textural differences in the rocks (i.e. the degree of cementation and the thickness of bedding/laminations). The Earthy Entrada silty sandstone is weakly cemented, very finely laminated, and has smaller grain size which make it more ductile. Conversely, the Curtis conglomerate shows thicker bedding, larger grain sizes, and strong cementing, making it less ductile than the Earthy Entrada. A propagating thrust fault may be impeded for longer (creating a larger amplitude fault propagation fold) in the more ductile of the two units.

These results shed light on the mechanics of thrust fault formation of a range of scales beyond that of the Ketobe Knob and other outcrop-scale structures (McConnell et al., 1997; Marshak et al., 2019, Fig. 11). Thrust faults that form in the ramp-first faulting style are observed in the foreland of large thrust belts, like the Canadian Rockies (Link, 1949; Teal, 1983; Morley, 1994; Begin et al., 1996; McMechan, 1999; Langenberg et al., 2006) the Osen-Røa thrust sheet in Norway (Morley, 1994), and the Wyoming thrust belt (Woodward, 1986; 
Fischer et al., 1992). Sometimes called "sled runners" or "incipient thrusts", small-displacement thrusts form 10 's $\mathrm{km}$ in front of the conventionally defined fold and thrust belt (McMechan, 1999). In seismic reflection profiles these faults appear to cut stiff sandstone units and lose displacement above and below in weaker reflections (Teal, 1983; McMechan, 1999).

\section{CONCLUSIONS}

We integrated traditional structural geology field methods, 2-dimensional cross section reconstructions, and finite element models to investigate the effects of mechanical stratigraphy on stress heterogeneity, rupture direction, and fault geometry by examining a large-scale field example of ramp-first faulting in central Utah. The results of this study provide strong support for the importance of the ramp-first faulting style in mechanically stratified systems. We have found that the mechanical stratigraphy of faulted rocks exerts a firstorder control on thrust fault formation. Kinematic reconstructions and finite element models indicate that faults at the Ketobe Knob nucleated in structurally strong (stiff, low ductility) layers, then propagated upward and downward, and created fault propagation folds at both fault tips. Numerical models provided a mechanical explanation for the kinematics; strong rock units showed elevated stresses and more brittle behavior making them likely to fault first. Weak units showed lower stresses, but were more likely to respond ductily and form folds under pressure. When a fault was nucleated in the layered system, the FEMs showed similar fold orientations as seen in the outcrop.

We hypothesize that in some cases thrust fault nucleation occurs in the ramp-first style that then evolve to ramps that are linked by flats (slip along long angle, weak surfaces) (Eisenstadt and De Paor, 1987; Marshak et al., 2019). Many thrust systems may originate in this way, but field evidence is hard to unravel due to the overprinting by later deformation. Because we rarely see complete thrust faults in the field from upper fault tip to lower fault tip, identifying large ramp-first faults in the field is not straightforward. However, stratigraphy, the position and shape of flanking folds, fault-displacement profiles, and balanced cross section restorations can provide clues to kinematics. This study emphasizes the importance of incorporating mechanics and knowledge of lithology into cross section restorations and the study of thrust fault kinematics.

Acknowledgements: Funding for this work was provided by support for Wigginton by the GDL Foundation, a Utah State University Graduate Research and Collaborative Opportunities grant, a Geological Society of America student research grant, an American Association of Petroleum Geologists student research grant, a grant from the Salt Lake City chapter of The Association of Women Geologists, and the Utah State University Geology Department J. S. Williams research grant. Academic discounts and access to Move and Abaqus software is gratefully acknowledged. 


\section{REFERENCES CITED}

Apotria, T.G., Wilkerson, M.S., 2002. Seismic expression and kinematics of a fault related fold termination: Rosario structure, Maracaibo Basin, Venezuela. Journal of Structural Geology, v. 24, p.671-687.

Aydin, A., and Basu, A., 2005, The Schmidt hammer in rock material characterization: Engineering Geology, v. 81, p. 1-14, doi: 10.1016/j.enggeo.2005.06.006.

Begin, N.J., Lawton, D.C., and Spratt, D.A., 1996, Seismic interpretation of the Rocky Mountain Thrust Front near the Crows nest Deflection, Southern Alberta: Bulletin of Canadian Petroleum Geology, v. 44, p. $1-$ 13, doi: 10.2113/gscpgbull.56.3.199.

Berger, P., and Johnson, A. M., 1982, Folding of passive layers and forms of minor structures near terminations of blind thrust faults - application to the central Appalachian blind thrust, Journal of Structural Geology, v. 4, p. 343-353.

Bourne, S.J., 2003, Contrast of elastic properties between rock layers as a mechanism for the initiation and orientation of tensile failure under uniform remote compression: Journal of Geophysical Research: Solid Earth, v. 108, p. 2580-2600, doi: 10.1029/2001JB001725.

Boyer, S.E., and Elliott, D., 1982, Thrust Systems: American Association of Petroleum Geologists Bulletin, v. 66, p. 1196-1230.

Busetti, S., and Fang, Z., 2018, Lithologic controls on shale rheology: A lookback on 7 years of mechanical testing: American Association of Petroleum Geologists Datapages/Search and Discovery, Article \#90323.

Butler, R.W.H., 1982, The terminology of structures in thrust belts: Journal of Structural Geology, v. 4, p. 239245, doi: 10.1016/0191-8141(82)90011-6.

Byerlee, J.D., 1978, Friction of Rocks: Birkhäuser, Basel, v. 116, p. 615-626.

Cawood, A. J., and Bond, C. E., 2020, Broadhaven revisited: a new look at models of fault-fold interaction, in: Bond, C. E. \& Lebit, H. D. (eds.) Folding and Fracturing of Rocks: 50 Years of Research since the Seminal Text Book of J. G. Ramsay. Geological Society, London, Special Publications, 487, 105126.

Chapman, T.J., and Williams, G.D., 1985, Strains developed in the hanging walls of thrusts due to their slip/propagation rate: a dislocation model: reply: Journal of Structural Geology, v. 7, p. 759-762, doi: 10.1016/0191-8141(85)90152-X.

Chester, J. S., 2003, Mechanical stratigraphy and fault-fold interaction, Absaroka thrust sheet, Salt River Range, Wyoming: Journal of Structural Geology, v. 25, p. 1171-1192, doi: 10.1016/S0191-8141(02)00151-7.

Chester, J. S., Logan, J. M., and Spang, J., 1991, Influence of layering and boundary conditions on fault-bend and fault-propagation folding, Geological Society of America Bulletin v. 103, p. 1059-1072. 
Cooke, M.L., and Underwood, C.A., 2001, Fracture termination and step-over at bedding interfaces due to frictional slip and interface opening: Journal of Structural Geology, v. 23, p. 223-238, doi: 10.1016/S01918141(00)00092-4.

Cooper, M.A., and Trayner, P.M., 1986, Thrust-surface geometry: implications for thrust-belt evolution and section-balancing techniques: Journal of Structural Geology, v. 8, p. 305-312, doi: 10.1016/01918141(86)90051-9.

Corbett, K, Friedman, M, and Spang, J. Fracture development and mechanical stratigraphy of Austin Chalk, Texas, Bulletin of American Association of Geologists v. 71, p.17-28.

Currie, J.B., Patnode, H.W., and Trump, R.P., 1962, Development of folds in sedimentary strata: Geological Society of America Bulletin, v. 73, p. 655-673, doi: 10.1130/0016-7606(1962)73[655:DOFISS]2.0.CO;2.

Dahlstrom, C.D.A., 1970, Structural geology in the eastern margin of the Canadian Rocky Mountains: Bulletin of Canadian Petroleum Geology, v. 18, p. 332-406.

Dassault Systèmes, 2016, ABAQUS® User Manual, SIMULIA, a division of Dassault Systèmes, Providence, Rhode Island:, http://130.149.89.49:2080/v2016/books/usb/default.htm?startat=pt04ch10s07at36.html\#usb-anl-aenrichment.

Doelling, H.H., Kuehne, P.A., Willis, G.C., and Ehler, J.B., 2015, 1:100,000 scale Geologic map of the San Rafael Desert 30’ x 60’ quadrangle, Emery and Grand Counties, Utah: Utah Geological Survey.

Eisenstadt, G., and De Paor, D.G., 1987, Alternative model of thrust-fault propagation: Geology, v. 15, p. 630633, doi: 10.1130/0091-7613(1987)15<630:AMOTP>2.0.CO;2.

Ellis, M.A., and Dunlap, W. J., 1988, Displacement variation along thrust faults: implications for the development of large faults: Journal of Structural Geology, v. 10, p. 183-192, doi: 10.1016/01918141(88)90115-0.

Erickson, G. S., 1996, Influence of mechanical stratigraphy on folding vs faulting: Journal of Structural Geology, v. 18, p. 443-450, doi: 10.1016/0191-8141(95)00064-K.

Ferrill, D.A., and Morris, A.P., 2008, Fault zone deformation controlled by carbonate mechanical stratigraphy, Balcones fault system, Texas: American Association of Petroleum Geologists Bulletin, v. 92, p. 359-380, doi: $10.1306 / 10290707066$.

Ferrill, D.A., Morris, A.P., McGinnis, R.N., Smart, K.J., Wigginton, S. S., and Hill, N.J., 2017, Mechanical stratigraphy and normal faulting: Journal of Structural Geology, v. 94, p. 275-302, doi: 10.1016/j.jpg.2016.11.010.

Ferrill, D.A., Morris, A.P., Wigginton, S.S., Smart, K.J., McGinnis, R.N., and Lehrmann, D., 2016, Deciphering thrust fault nucleation and propagation and the importance of footwall synclines: Journal of Structural Geology, v. 85, p. 1-11, doi: 10.1016/j.jsg.2016.01.009.

Fischer, M.P., and Jackson, P.B., 1999, Stratigraphic controls on deformation patterns in fault-related folds: a detachment fold example from the Sierra Madre Oriental, northeast Mexico: Journal of Structural Geology, v. 21, p. 613-633, doi: 10.1016/S0191-8141(99)00044-9. 
Fischer, M. P., Woodward, N. B., Mitchell, M. M., 1992, The kinematics of break-thrust folds, Journal of Structural Geology, v. 14, p. 451-460.

Gercek, H., 2007, Poisson's ratio values for rocks: International Journal of Rock Mechanics and Mining Sciences, v. 44, p. 1-13, doi: 10.1016/j.ijrmms.2006.04.011.

Goodman, R.E., 1980, Introduction to Rock Mechanics: Wiley, 582 p.

Grasemann, B., Martel, S., and Passchier, C., 2005, Reverse and normal drag along a fault: Journal of Structural Geology, v. 27, p. 999-1010, doi: 10.1016/j.jsg.2005.04.006.

Grasemann, B., Stüwe, K., and Vannay, J.-C., 2003, Sense and non-sense of shear in flanking structures: Journal of Structural Geology, v. 25, p. 19-34, doi: 10.1016/S0191-8141(02)00012-3.

Gross, M.R., Fischer, M.P., Engelder, T., and Greenfield, R.J., 1995, Factors controlling joint spacing in interbedded sedimentary rocks: integrating numerical models with field observations from the Monterey Formation, USA: Geological Society, London, Special Publications, v. 92, p. 215-233, doi: 10.1144/GSL.SP.1995.092.01.12.

Gutiérrez-Alonso, G., and Gross, M.R., 1999, Structures and mechanisms associated with development of a fold in the Cantabrian Zone thrust belt, NW Spain: Journal of Structural Geology, v. 21, p. 653-670, doi: 10.1016/S0191-8141(99)00055-3.

Hedayat, A., Ochoa-Cornejo, F., and Khasawneh, Y., 2015, Numerical simulation of crack initiation and growth in rock specimens containing a flaw under uniaxial compression, in Conference: 49th US Rock Mechanics/Geomechanics Symposium, At San Francisco, CA, USA.

Hughes, A.N., Benesh, N.P., and Shaw, J.H., 2014, Factors that control the development of fault-bend versus fault-propagation folds: Insights from mechanical models based on the discrete element method (DEM): Journal of Structural Geology, v. 68, p. 121-141, doi: 10.1016/j.jsg.2014.09.009.

Hughes, A.N., and Shaw, J.H., 2014, Fault displacement-distance relationships as indicators of contractional fault-related folding style, American Association of Petroleum Geologists Bulletin, v. 98, p. 227-251.

Hughes, A.N., and Shaw, J.H., 2015, Insights into the mechanics of fault-propagation folding styles: Geological Society of America Bulletin, v. 127, p. 1752-1765, doi: 10.1130/B31215.1.

Katz, O., Reches, Z., and Roegiers, J.C., 2000, Evaluation of mechanical rock properties using a Schmidt Hammer: v. 37, p. 723-728, doi: doi.org/10.1016/S1365-1609(00)00004-6.

Koyi, H.A., and Teixell, A., 1999, Where is the footwall flat? A cautionary note on template constraints: Journal of Structural Geology, v. 21, p. 373-377, doi: 10.1016/S0191-8141(99)00009-7.

Langenberg, C.W., Beaton, A., and Berhane, H., 2006, Regional evaluation of the coalbed-methane potential of the Foothills/Mountains of Alberta, Canada: International Journal of Coal Geology, v. 65, p. 114-128, doi: 10.1016/j.coal.2005.04.010.

Larsen, E.B., 2015, Geomechanical and Structural characteristics of a paleoreservoir-caprock succession; sandstones of Humbug Flats, Central Utah, Master's Thesis: University of Oslo. 
Larsen, B., Grunnaleite, I., and Gudmundsson, A., 2010, How fracture systems affect permeability development in shallow-water carbonate rocks: An example from the Gargano Peninsula, Italy: Journal of Structural Geology, v. 32, p. 1212-1230, doi: 10.1016/j.jsg.2009.05.009.

Laubach, S.E., Olson, J.E., and Gross, M.R., 2009, Mechanical and fracture stratigraphy: American Association of Petroleum Geologists Bulletin, v. 93, p. 1413-1426, doi: 10.1306/07270909094.

Marshak, S., Haqb, S. S. B., Sen, P., 2019, Ramp initiation in fold-thrust belts: Insight from PIV analysis of sandbox models, Journal of Structural Geology, v. 118, p. 308-323, https:// doi.org/10.1016/j.jsg.2018.11.006.

McClay, K.R. (Ed.), 1992, Thrust Tectonics: Dordrecht, Springer Netherlands, doi: 10.1007/978-94-011-30660.

McClay, K. R., 2011, Introduction to Thrust Fault-related Folding, in: McClay, K. R., Shaw, J. H., \& Suppe, J. eds., Thrust fault-related folding. Tulsa, OK: American Association of Petroleum Geologists Memoir 94, p. 1 21.

McConnell, D.A., Kattenhorn, S.A., and Benner, L.M., 1997, Distribution of fault slip in outcrop-scale faultrelated folds, Appalachian Mountains: Journal of Structural Geology, v. 19, p. 257-267, doi: doi.org/10.1016/S0191-8141(96)00094-6.

McGinnis, R.N., Ferrill, D.A., Morris, A.P., Smart, K.J., and Lehrmann, D., 2017, Mechanical stratigraphic controls on natural fracture spacing and penetration: Journal of Structural Geology, v. 95, p. 160-170, doi: 10.1016/j.jsg.2017.01.001.

McMechan, M.E., 1999, Geometry of the Structural Front in the Kakwa Area, Northern Foothills of Alberta: Bulletin of Canadian Petroleum Geology, v. 47, p. 31-42.

Mitra, S. 1990, Fault-propagation folds: Geometry, kinematic evolution, and hydrocarbon traps: American Association of Petroleum Geologists Bulletin, v. 74, p. 921-945.

Mitra, S., and Mount, V.S., 1998, Foreland Basement-Involved Structures: American Association of Petroleum Geologists Bulletin, v. 82, p. 70-109, doi: 10.1306/1D9BC39F-172D-11D7-8645000102C1865D.

Morley, C.K., 1994, Fold-generated imbricates: examples from the Caledonides of Southern Norway: Journal of Structural Geology, v. 16, p. 619-631, doi: 10.1016/0191-8141(94)90114-7.

Muraoka, H., and Kamata, H., 1983, Displacement distribution along minor fault traces: Journal of Structural Geology, v. 5, p. 483-495, doi: 10.1016/0191-8141(83)90054-8.

Neuhauser, K.R., 1988, Sevier-age ramp-style thrust faults at Cedar Mountain, northwestern San Rafael Swell (Colorado Plateau), Emery County, Utah: Geology, v. 16, p. 299-302, doi: 10.1130/00917613(1988)016<0299:SARSTF>2.3.CO;2.

Newson, A. C., 2015, Imaging the Overturned Limb of a Footwall Syncline and its Impact on Exploration in Fold and Thrust Belts, Recorder, Canadian Society of Exploration Geophysicists, v. 40. 
Odonne, F., 1990, The control of deformation intensity around a fault: natural and experimental examples: Journal of Structural Geology, v. 12, p. 911-921, doi: 10.1016/0191-8141(90)90064-6.

Patton, T.L., and Fletcher, R.C., 1995, Mathematical block-motion model for deformation of a layer above a buried fault of arbitrary dip and sense of slip: Journal of Structural Geology, v. 17, p. 1455-1472, doi: 10.1016/0191-8141(95)00034-B.

Petrie, E. S., Sundal, A. J., Wigginton, S. S., and Evans, J. P., 2018, Damage Zone Structure and Structural Diagenesis Associated with Thrust Faults - Emery County, Utah, American Association Petroleum Geologists, Annual meeting, Salt Lake City, Utah, Search and Discovery Article \#51520, DOI:10.1306/51520Petrie2018, https://www.searchanddiscovery.com/documents/2019/51520petrie/ndx_petrie.pdf.

Petrie, E.S., and Evans, J.P., 2016, Modeling strain across mechanical sedimentary lithologic interfaces: geomechanical models derived from outcrop analysis: Bulletin of Canadian Petroleum Geology, v. 64, p. 477-494, doi: 10.2113/gscpgbull.64.4.477.

Petrie, E. S., Evans, J. P. and Bauer, S. J., 2014, Failure of cap-rock seals as determined from mechanical stratigraphy, stress history, and tensile-failure analysis of exhumed analogs, American Association of Petroleum Geologists Bulletin v. 98, p. 2365-2389.

Petrie, E. S., Evans, J. P. and Bauer, S. J., 2015, Determining the effect mechanical rock properties have on variability in fracture gradients, AAPG Datapages/Search and Discovery Article \#90216, AAPG Annual Convention and Exhibition, Denver, CO.

Petrie, E. S., Jeppson, T. N., and Evans, J. P., 2012, Predicting rock strength variability across stratigraphic interfaces in caprock lithologies at depth: Correlation between outcrop and subsurface, Environmental Geosciences v. 19, p. 125-142.

Ramsay, J.G., 1992, Some geometric problems of ramp-flat thrust models, in McClay K.R. (eds.) Thrust Tectonics. Springer, Dordrecht, p. 191-200, doi: https://doi.org/10.1007/978-94-011-3066-0_17.

Reches, Z., and Eidelman, A., 1995, Drag along faults: Tectonophysics, v. 247, p. 145-156, doi: 10.1016/00401951(94)00170-E.

Roche, V., Homberg, C., and Rocher, M., 2013, Fault nucleation, restriction, and aspect ratio in layered sections: Quantification of the strength and stiffness roles using numerical modeling: Fault modeling in layered sections: Journal of Geophysical Research: Solid Earth, v. 118, p. 4446-4460, doi: 10.1002/jgrb.50279.

Rodgers, D.A., and Rizer, W.D., 1981, Deformation and secondary faulting near the leading edge of a thrust fault: Geological Society, London, Special Publications, v. 9, p. 65-77, doi: 10.1144/GSL.SP.1981.009.01.07.

Schmidt, C. J., Evans, J. P., Harlan, S. S., Weberg,E.D., Brown, J. S., Batatian, D., err, D.N., Malizzi, L., McDowell, R. J., Nelson, G. C., Parke, M., and Genovese, P. W., 1993, Mechanical behavior of basement rocks during movement of the Scarface thrust, central Madison Range, Montana, in: Schmidt, C. J.,Chase,R. 
B., and Erslev, E.A., eds., Laramide Basement Deformation in the Rocky Mountain Foreland of the Western United States, Geological Society of America Special Paper 280, p. 89-106.

Serra, S., 1977, Styles of deformation in the ramp regions of overthrust faults, Rocky Mountain Thrust Belt, Geology and Resources, Wyoming Geological Association Guidebook 28, p. 487-498.

Sivakumar, G., and Maji, V.B., 2016, Simulation of crack propagation in rocks by XFEM, doi: 10.2991/rare16.2016.46.

Smart, K.J., Ferrill, D.A., Morris, A.P., Bichon, B.J., Riha, D.S., and Huyse, L., 2010, Geomechanical modeling of an extensional fault-propagation fold: Big Brushy Canyon monocline, Sierra Del Carmen, Texas: American Association of Petroleum Geologists Bulletin, v. 94, p. 221-240, doi: 10.1306/08050908169.

Smart, K.J., Ferrill, D.A., Morris, A.P., and McGinnis, R.N., 2012, Geomechanical modeling of stress and strain evolution during contractional fault-related folding: Tectonophysics, v. 576-577, p. 171-196, doi: 10.1016/j.tecto.2012.05.024.

Smart, K.J., Ofoegbu, G.I., Morris, A.P., McGinnis, R.N., and Ferrill, D.A., 2014, Geomechanical modeling of hydraulic fracturing: Why mechanical stratigraphy, stress state, and pre-existing structure matter: American Association of Petroleum Geologists Bulletin, v. 98, p. 2237-2261, doi: 10.1306/07071413118.

Strayer, L.M., Hudleston, P.J., 1997. Numerical modeling of fold initiation at thrust ramps, Journal of Structural Geology, v. 19, p. 551-566.

Suppe, J., 1983, Geometry and kinematics of fault-bend folding: American Journal of Science, v. 283, p. 684721, doi: $10.2475 /$ ajs.283.7.684.

Suppe, J., and Medwedeff, D.A., 1990, Geometry and kinematics of fault-propagation folding: Eclogae Geologicae Helvetiae, v. 83, p. 409-454, doi: 10.1016/j.cnsns.2016.07.026.

Tavani, S., Storti, F., and Salvini, F., 2006, Double-edge fault-propagation folding: geometry and kinematics: Journal of Structural Geology, v. 28, p. 19-35, doi: 10.1016/j.jsg.2005.09.007.

Teal, R.R., 1983, The triangle zone at Cabin Creek, Alberta Canada: American Association of Petroleum Geologists Studies in Geology, v. 15, doi: doi.org/10.1306/St15433431432.

Teixell, A., and Koyi, H.A., 2003, Experimental and field study of the effects of lithological contrasts on thrustrelated deformation: Tectonics, v. 22, doi: 10.1029/2002TC001407.

Underwood, C.A., Cooke, M.L., Simo, J.A., and Muldoon, M.A., 2003, Stratigraphic controls on vertical fracture patterns in Silurian dolomite, northeastern Wisconsin: American Association of Petroleum Geologists Bulletin, v. 87, p. 121-142, doi: 10.1306/072902870121.

Uzkeda, H., Poblet, J., and Bulnes, M., 2010, A geometric and kinematic model for double-edge propagating thrusts involving hanging wall and footwall folding. An example from the Jaca-Pamplona Basin (Southern Pyrenees): Geological Journal, v. 45, p. 506-520, doi: 10.1002/gj.1205.

Wacker, M.A., 2001, Geometry and kinematics of thrust related drag folds: an example from the San Rafael Swell, Central Utah, Thesis: Florida International University. 
Wigginton, Sarah S., "The Influence of Mechanical Stratigraphy on Thrust-Ramp Nucleation and Propagation of Thrust Faults" (2018), Master's thesis, Utah State University, Logan, Graduate Theses and Dissertations. 7344, https://digitalcommons.usu.edu/etd/7344.

Williams, G., and Chapman, T., 1983, Strains developed in the hanging walls of thrusts due to their slip/propagation rate: a dislocation model: Journal of Structural Geology, v. 5, p. 563-571, doi: doi.org/10.1016/0191-8141(83)90068-8.

Woodward, n. B., 1986, Thrust fault geometry of the Snake River Range, Idaho and Wyoming, Geological Society of America Bulletin, v. 97, p. 178-193.

Woodward, N.B., and Rutherford, E., 1989, Structural lithic units in external orogenic zones: Tectonophysics, v. 158, p. 247-267, doi: 10.1016/0040-1951(89)90327-2.

Zhuang, X., Chun, J., and Zhu, H., 2015, A comparative study on unfilled and filled crack propagation for rocklike brittle material, doi: doi.org/10.1016/j.tafmec.2014.04.004. 
Table 1. Schmidt hammer results, and calculated UCS and Young's moduli for the rocks in the study.

\begin{tabular}{|c|c|c|c|}
\hline $\begin{array}{l}\text { Mechanical } \\
\text { Unit }\end{array}$ & Average Rebound (R) & UCS (MPa) & E (GPa) \\
\hline Curtis SS & 38.1 & 28.4 & 9.8 \\
\hline $\begin{array}{l}\text { Curtis } \\
\text { conglomerate }\end{array}$ & 40.7 & 33.7 & 12.0 \\
\hline $\begin{array}{l}\text { Entrada } \quad \text { SS } \\
\text { (upper) }\end{array}$ & 49.8 & 62.1 & 22.5 \\
\hline Earthy Entrada & 39.3 & 30.7 & 10.8 \\
\hline $\begin{array}{l}\text { Entrada } \quad \text { SS } \\
\text { (lower) }\end{array}$ & 45.9 & 47.8 & 17.5 \\
\hline \multicolumn{2}{|c|}{ Conversion Equations ${ }^{\dagger}$} & $\ln (\mathrm{UCS})=0.792+0.067 \times \mathrm{R}$ & $\ln (E)=-0.967+3.091 \times \ln R$ \\
\hline $\begin{array}{l}\text { (UCS) } \\
{ }^{\dagger} \text { (Aydin and } \mathrm{Ba}\end{array}$ & $\begin{array}{l}\text { niaxial Compressive } \\
\text { u, 2005; Katz et al., 2000) }\end{array}$ & Stress, & Modulus \\
\hline
\end{tabular}

Table 2. Parameters used for material properties of the rock units

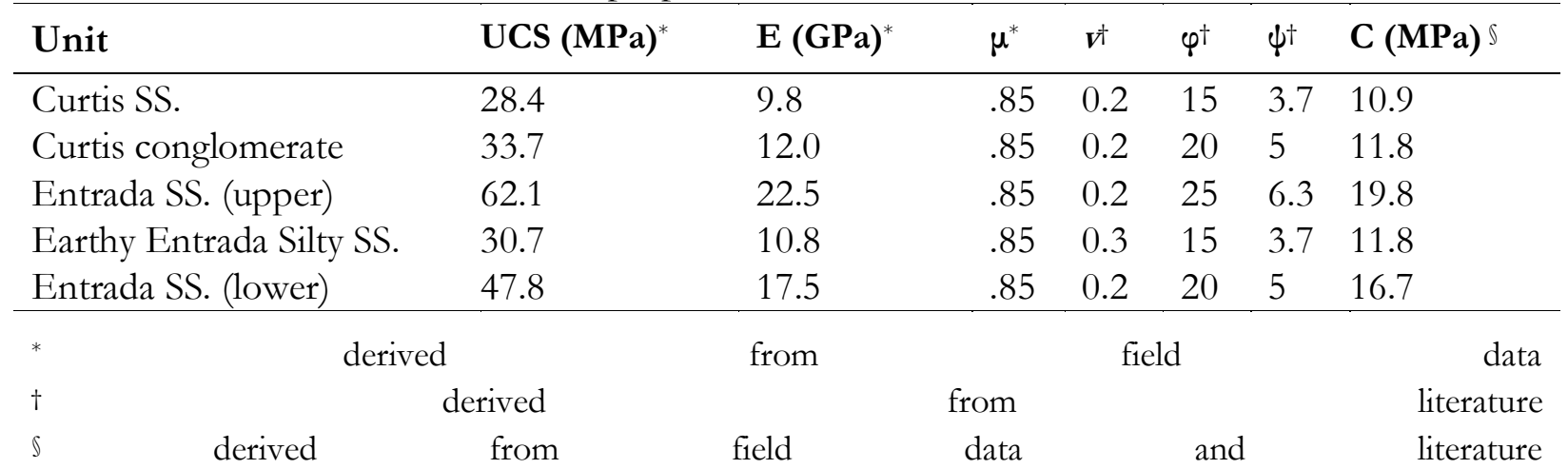

Uniaxial Compressive Stress (UCS), Young's Modulus (E), Static and Kinetic coefficients of friction $(\mu)$, Poisson's Ratio (v) (Gercek, 2007), Friction Angle $(\varphi)$ (Smart et al., 2014), and Dilation Angle ( $\psi$ ) (Smart et al., 2014), Cohesion yield stress (C) (Goodman, 1980) (C=UCS/ $\left(2 * \tan \left(45+.5^{*} \varphi\right)\right)$.

Table 3. Pressure loads applied to unfaulted and faulted models

\begin{tabular}{|c|c|c|c|c|}
\hline Step & Time Period (s) & $\sigma_{1}$ (MPa)* & $\sigma_{3} \mathbf{~ M P a )} \dagger$ & Gravity (m/s $\mathbf{s}^{2}$ \\
\hline $\mathbf{1}$ (Gravity) & $0-1$ & - & - & -9.80 \\
\hline $\mathbf{2}$ (Pressure) & $1-2$ & 200 & 40 & -9.80 \\
\hline
\end{tabular}


* $\sigma_{1}$ is horizontal

${ }^{\dagger} \boldsymbol{\sigma}_{3}$ is vertical (downward)

Table 4. Loads applied to the faulted model deformed with a displacement load

\begin{tabular}{|c|c|c|c|c|c|}
\hline Step & Time (s) & $\sigma_{1}(\mathrm{MPa})^{*}$ & $\sigma 3(\mathrm{MPa})^{\dagger}$ & $\begin{array}{c}\text { Gravity } \\
\left(\mathbf{m} / \mathbf{s}^{2}\right)\end{array}$ & Displacement (m) \\
\hline Initial & 0 & 52 & 40 & - & - \\
\hline 1 (Gravity) & $0-1$ & 52 & 40 & -9.80 & - \\
\hline 2 (Displacement) & $1-2$ & 52 & 40 & -9.80 & 2 \\
\hline \multicolumn{6}{|c|}{$\begin{array}{l}{ }^{*} \boldsymbol{\sigma}_{1} \text { is horizontal } \\
\boldsymbol{\sigma}_{3} \text { is vertical (downward) }\end{array}$} \\
\hline
\end{tabular}




\section{FIGURE CAPTIONS}

Figure 1. Models and interpretations of thrust fault development in anisotropic rocks. A) The early ramp model of Eisenstadt and DePaor (1987) in which thrust faults initiate in the stronger horizons and subsequent shortening is accommodated by linkage in the weakened layers of the early ramps. B) Interpretation of a field expression of upper and lower fault tip to fold transitions from McConnell et al. (1997). C) Fault-tip folding, and lower fault syncline development, from Ferrill et al. (2016).

Figure 2. A geologic map of the Ketobe Knob outcrop area (modified from Wacker, 2001; Witkind, 2004; Petrie et al., 2018). The Ketobe thrust structure is part of a lateral ramp structure that is part of a northnortheast trending thrust complex that cuts gently north, northeast and northwest dipping Jurassic strata at the northern end of the San Rafael Swell, central Utah.

Figure 3. Outcrop view looking to the northwest at the Ketobe Knob thrust. Rocks in the hanging wall display a small anticline above the fault at the northeast side. The footwall is characterized by a small syncline (exposed in dip and strike views). The fault consists of several sub-parallel southward-dipping strands. The fault is exposed in the dip-section on the southeast and northwest sides of the precipice, and the lower tip region is exposed in the strike section along the lower left of this view.

Figure 4. Stratigraphy of the Ketobe Knob outcrop. A) The Entrada and Curtis formations are separated into 5 units based on their sedimentology and mineralogy. B) Schmidt rebound values from each of the 5 units show distinct mechanical strengths, from Wigginton, 2018).

Figure 5. Major reconstruction steps of the 2D cross section restoration in Move $e^{\mathrm{TM}}$. A) The present day configuration of the outcrop. B-E) Progressive, sequential restoration steps are shown for the preferred model. The preferred model restores with the best line length balance, and fewest gaps that develop during modeling.

Figure 6. Displacement vs distance graphs for the major faults based on the preferred restored cross section. A) the uppermost fault, B) the middle fault and, C) the lowest fault. Shaded area under the curves show the unit cut by the fault. See Figure 4 for color key for units.

Figure 7. Boundary and loading conditions for mechanical models in ABAQUSTM. A) Boundary conditions and loads applied to the stratigraphic package for the unfaulted and faulted models deformed by pressure loads. The model is $\sim 30 \mathrm{~m}$ high and $50 \mathrm{~m}$ wide. The model was run with uniform $1 \mathrm{~m}$ mesh. B) Boundary 
conditions applied to the faulted model deformed with a displacement boundary condition. Additional material was added to the base and sides to reduce edge effects. The model was run with $1 \mathrm{~m}$ mesh in the interior $50 \mathrm{~m}$ and larger mesh in the areas with buffer material.

Figure 8. Model results from unfaulted finite element models with variation in mechanical stratigraphy after the end of the loading step. Interlayer friction coefficient is $\mu=0.85$. A) Color contours show the maximum compressive stress values. B) Black vectors show the orientation of the maximum principal stress trajectories through the model. C) Plot of stress with depth at the centerline of the model (see Figure 7 for color key).

Figure 9. A) Stress-time and B) stress-strain curves for the intact models. The inflection points on the curves indicate a transition from elastic to plastic deformation. C) Stress as a function of time during the loading step in the units above the upper fault tip (Curtis conglomerate) and below the lower fault tip (Earthy Entrada silty sandstone) in the faulted model shown in Figure 12. D) Graph of stress over time in each unit from Figure 15. Stresses rise rapidly as the load is applied, then levels off for the rest of the loading steps.

Figure 10. Models of unfaulted rocks with variation in mechanical stratigraphy and variations in interlayer friction. A) frictionless slip, B) $\mu=0.2$, C) $\mu=0.4$, and D) $\mu=0.85$. The color contours show the maximum compressive stress. E) Displacement profiles for the left edge of the model at the end of each model run for the different values of $\mu$, as shown.

Figure 11. Results from faulted FEM with no variation in mechanical stratigraphy after the end of the loading step. Interlayer friction coefficient is $\mu=0.85$. A) Color contours show the maximum compressive stress. B) Black vectors show the orientation of the maximum principal stress.

Figure 12. Results from the FEM of the faulted model with variation in mechanical stratigraphy. Interlayer friction is $\mu=0.85$. In the faulted model we assigned a friction coefficient of $\mu=0.4$ to the fault surface. A) Color contours show the maximum compressive stress. Areas shaded in black have stresses $>300 \mathrm{MPa}$. B) Black vectors show the orientation of the maximum principal stresses. Stresses are highest in the direct footwall of the lower tip of the fault.

Figure 13. Finite element model with a fault and variations in mechanical strength deformed by a displacement boundary condition. A) Schematic view of the model domain. B) Results of the model showing maximum principal stress in $\mathrm{MPa}$. C) Vectors show the orientation of the maximum principal stress. D) Hanging wall anticline and footwall syncline development at fault tips. 
Figure 14. Mechanics of stress distribution and potential failure in Mohr-Coulomb space. A) Stress-depth profile for the intact rock model (from Figure 8c). Yellow line indicates the starting applied stress of 200 MPa. B) Representation of stresses in the mechanically stratified section. At the start of the loading $\sigma_{1}=$ $200 \mathrm{MPa}$, and the vertical load, $\sigma_{2}=40 \mathrm{MPa}$. As the stresses are applied through the layers, stresses in the weaker horizons (b) drop and increase in the stronger section (c). Failure may occur in the strong section before the weaker rocks in cases where the combination of cohesive and frictional strengths are reached by the increased stresses in the strong section while the weaker rocks experience stress reductions below failure. 
A
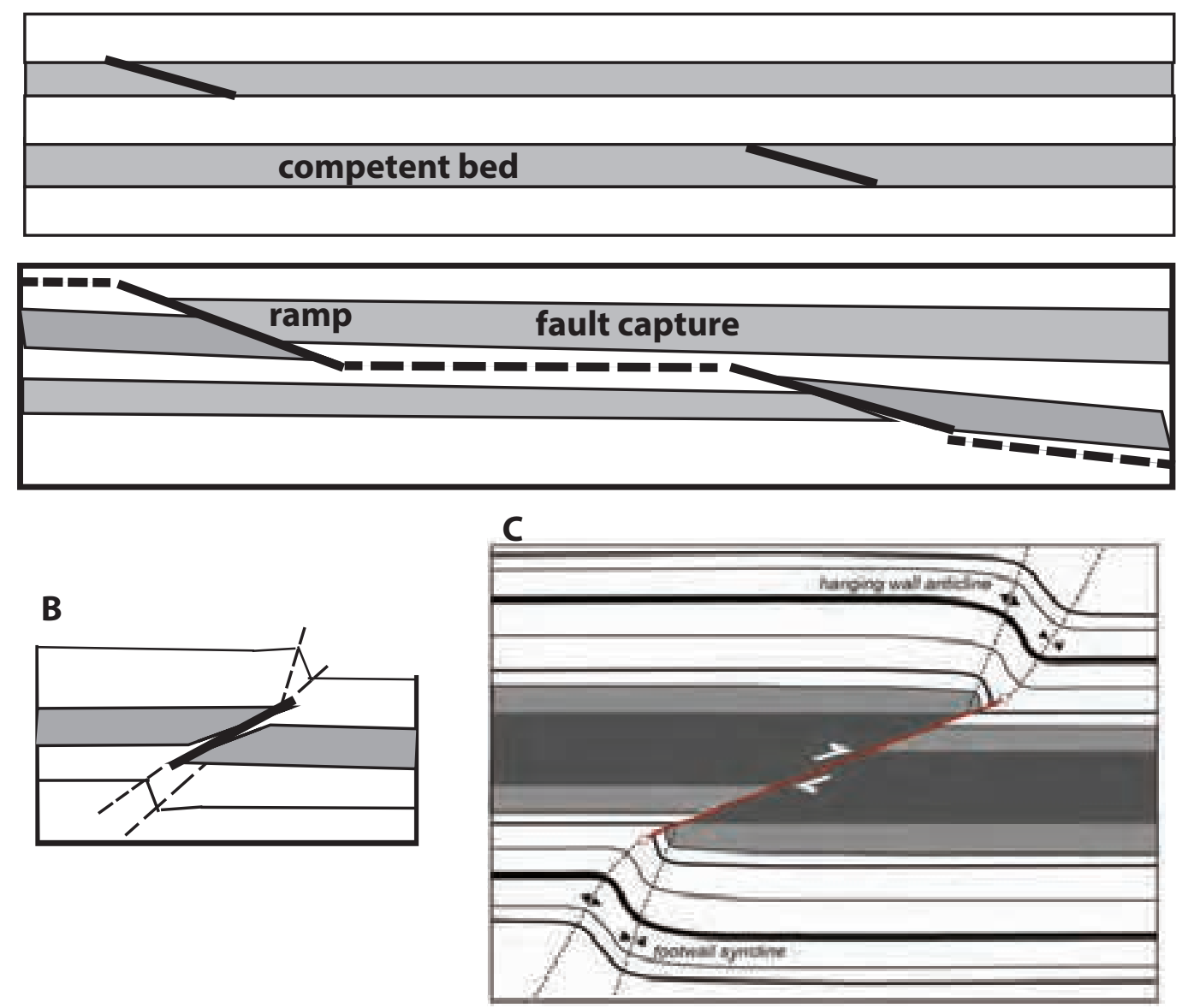

Figure 1. Wigginton et al., 2021 preprint 22 July 2021 


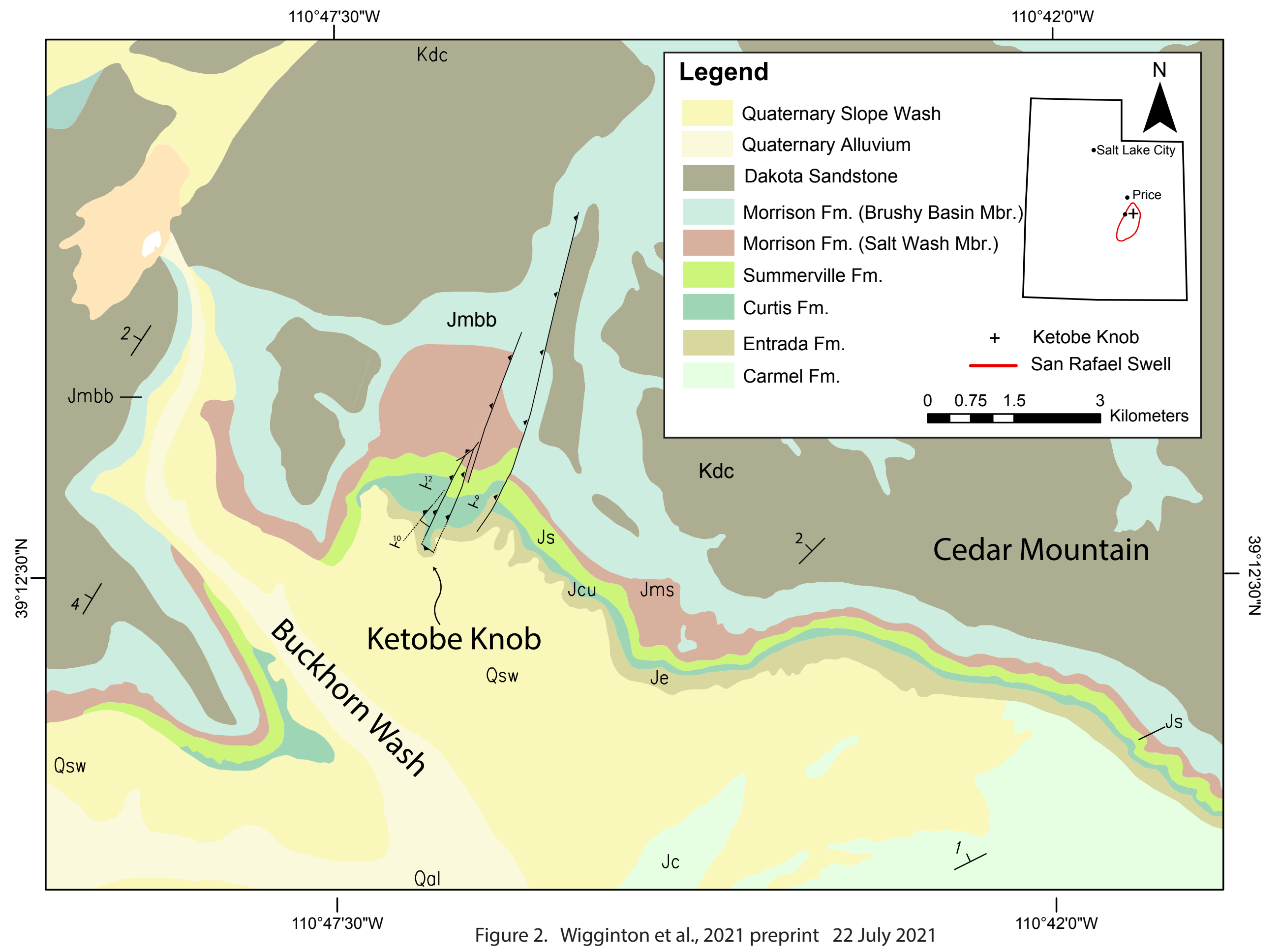


Figure 3. Wigginton et al., 2021 preprint 22 July 2021

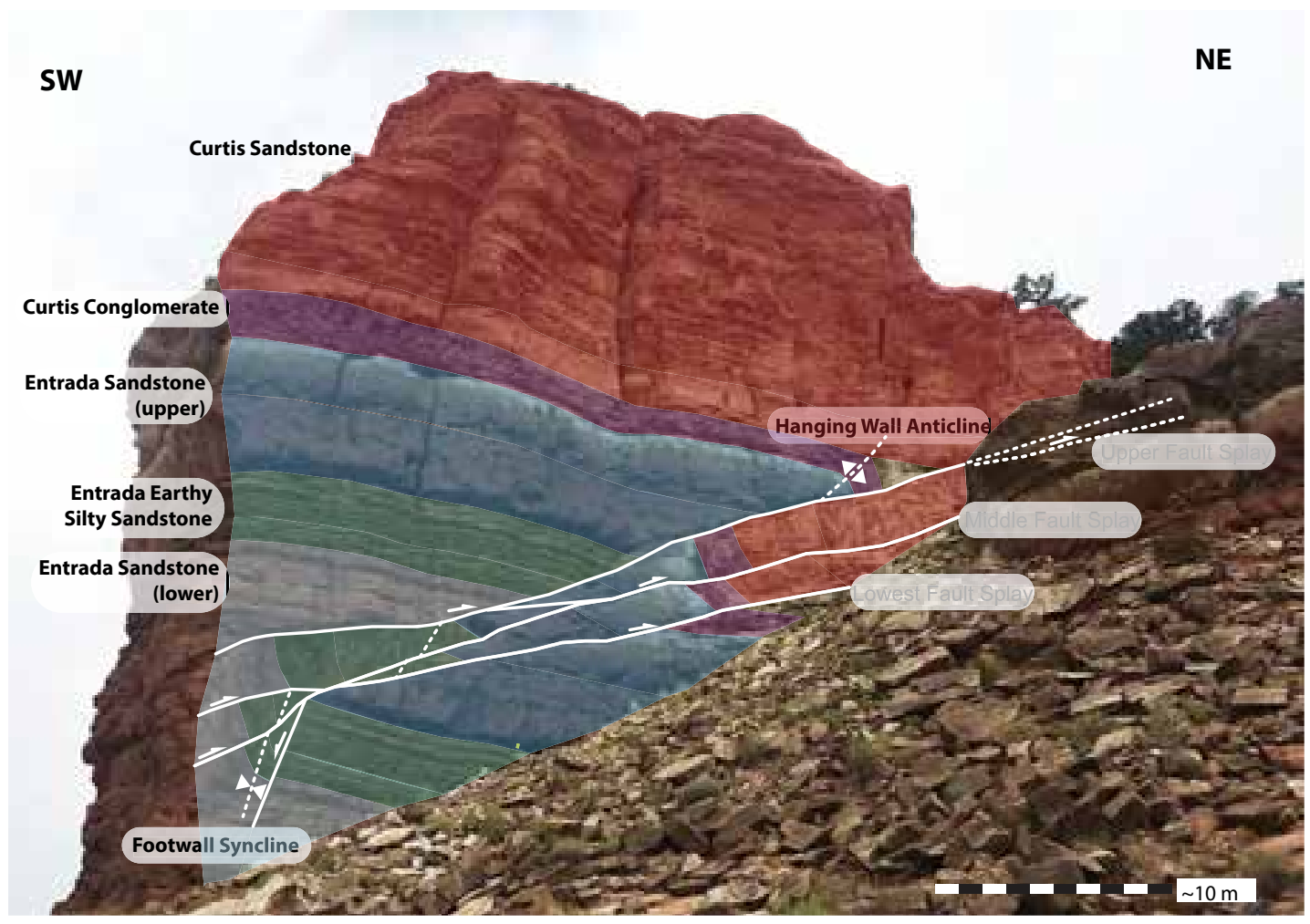



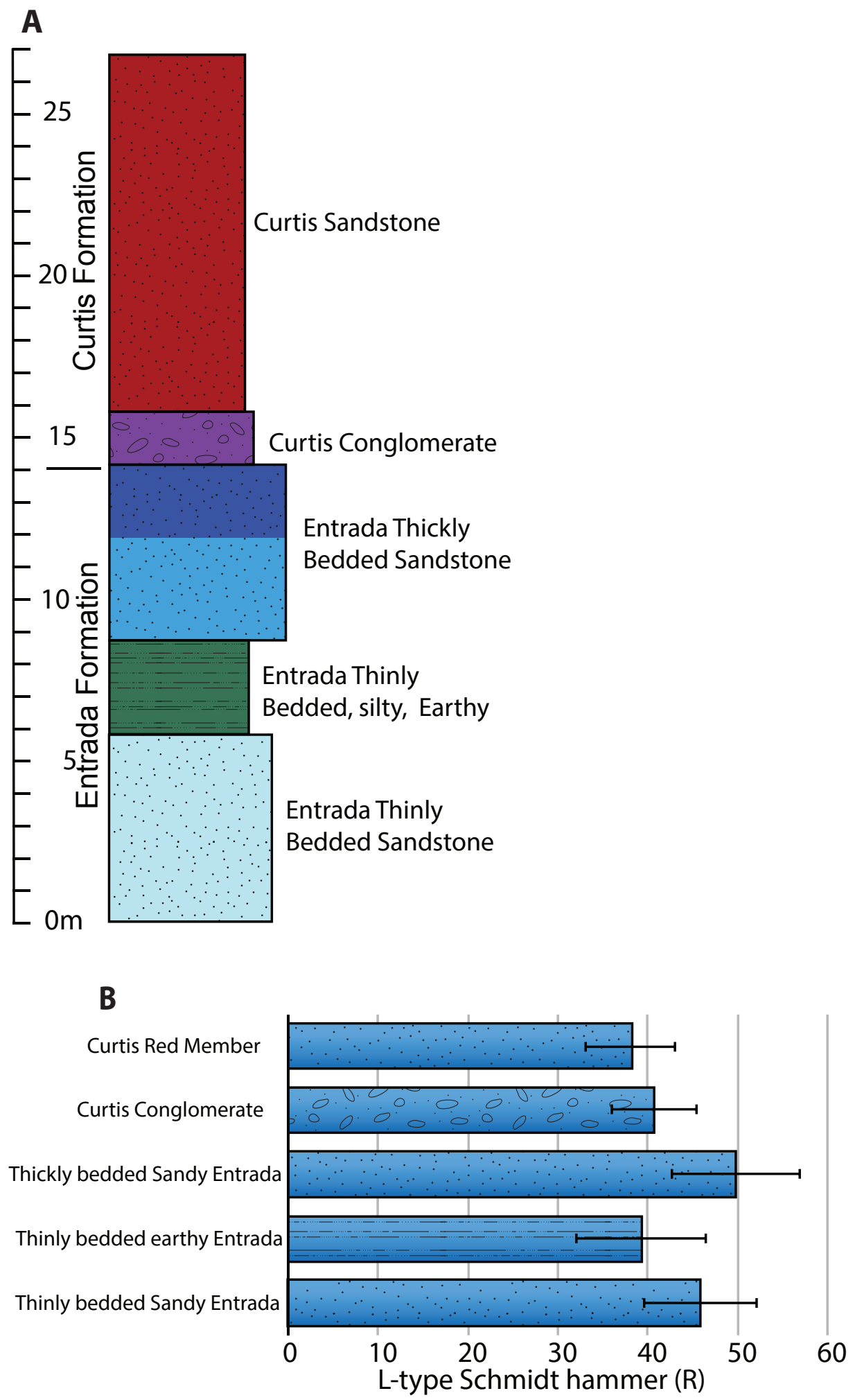

Figure 4. Wigginton et al., 2021 preprint 22 July 2021 


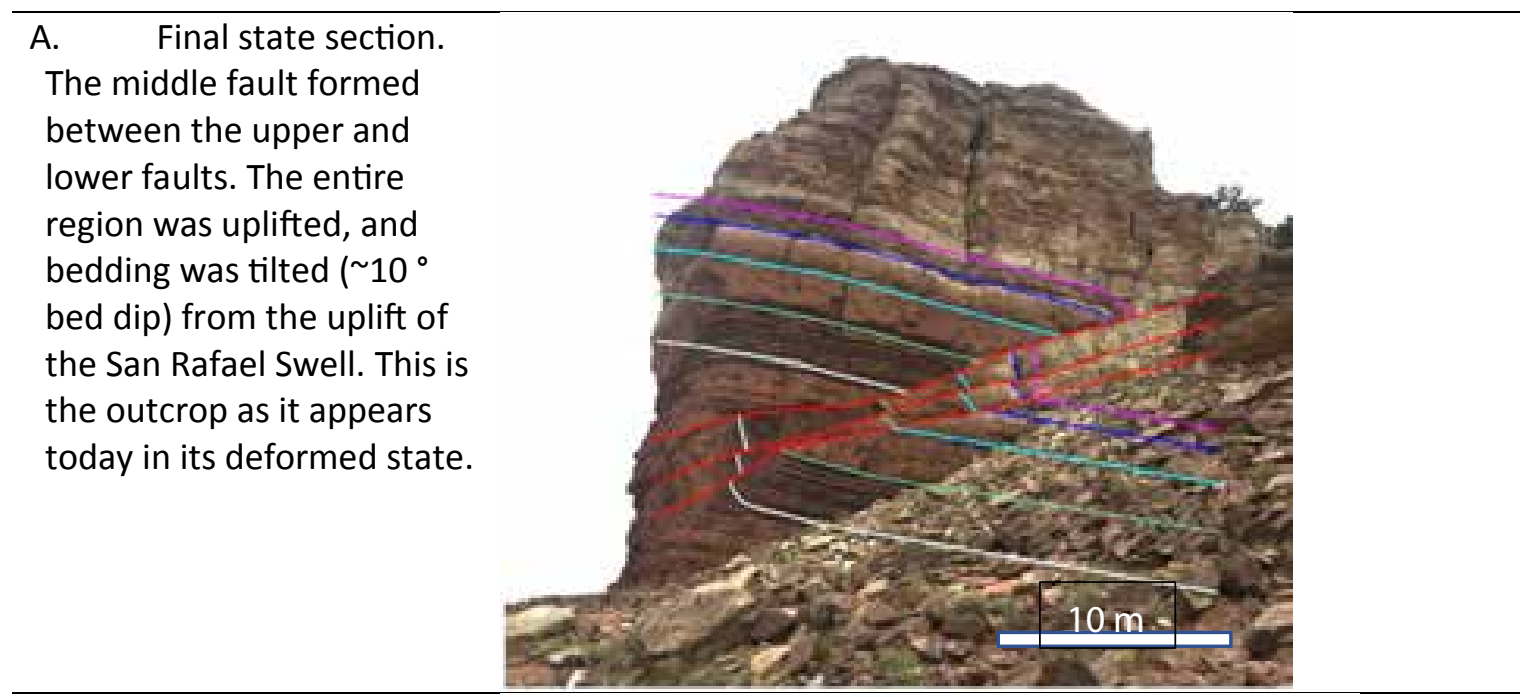

B. Progressive displacement on the lower fault, layers inbetween the upper and lower fault were steeply tilted.

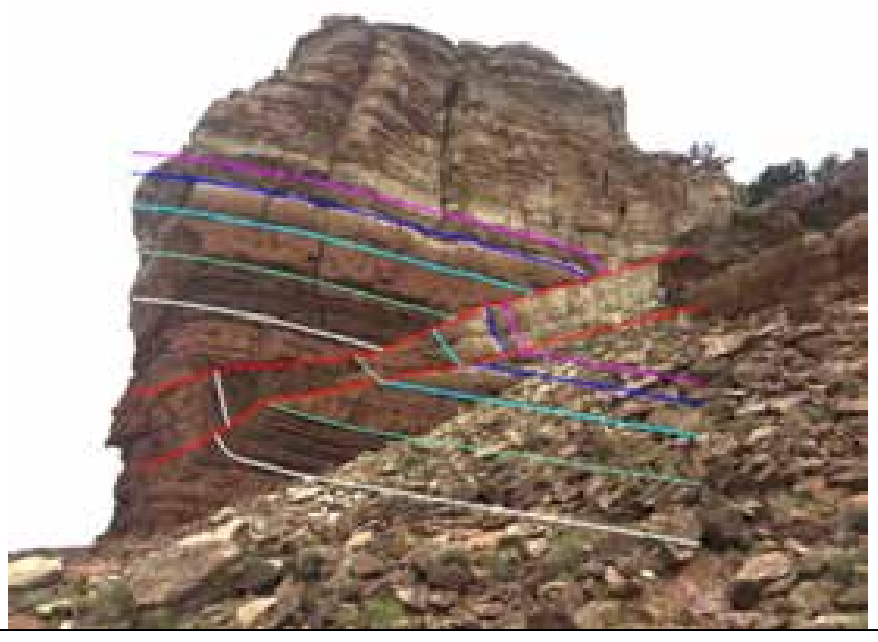

C. Nucleation on the lower fault near the base of the upper Entrada sandstone propagated upward and downward. The downward propagation of the fault created a footwall syncline in the Earthy Entrada silty sandstone.

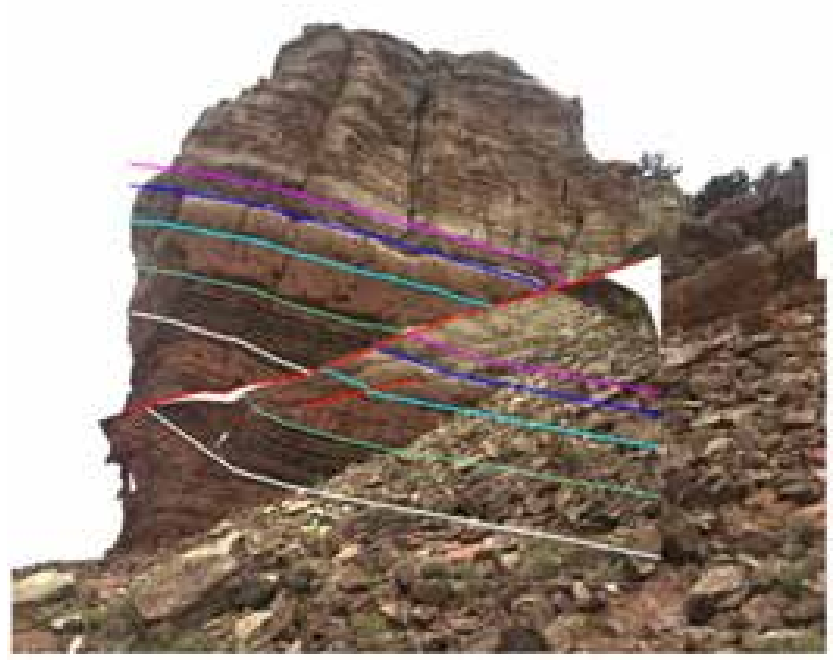

Figure 5. Wigginton et al., 2021 preprint 22 July 2021 


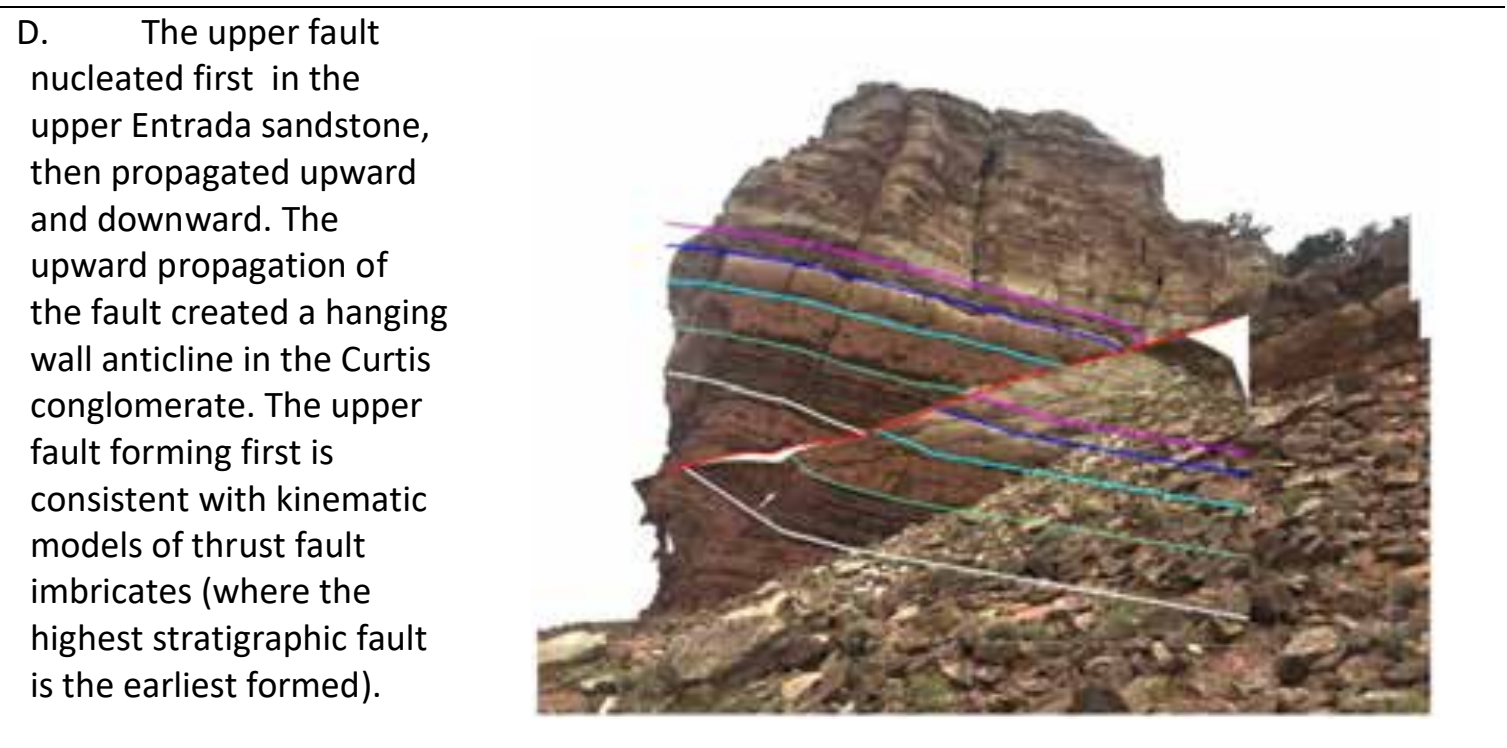

E. Original state section. Some gentle folding of the layers is interpreted to be present prior to faulting, with a very shallow regional north dip preserved.

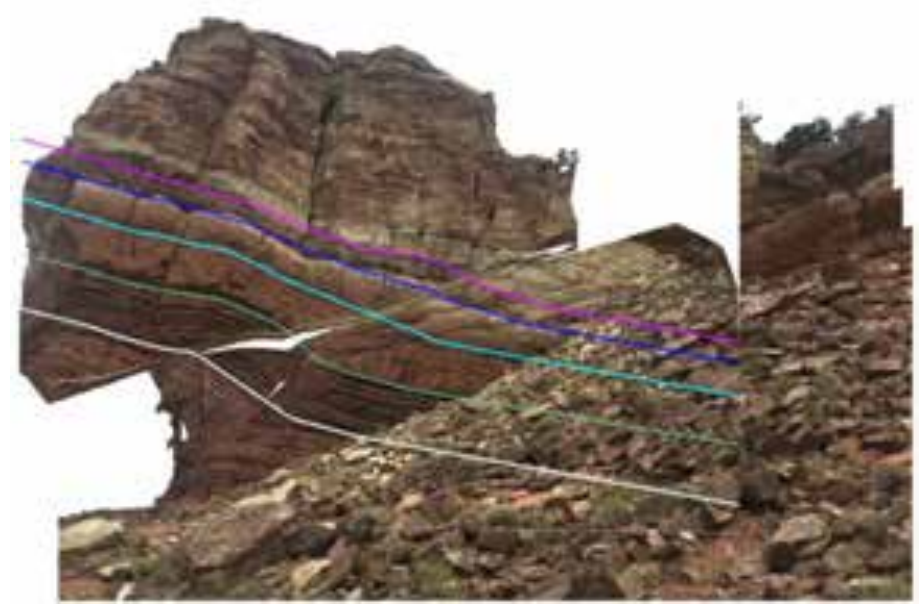



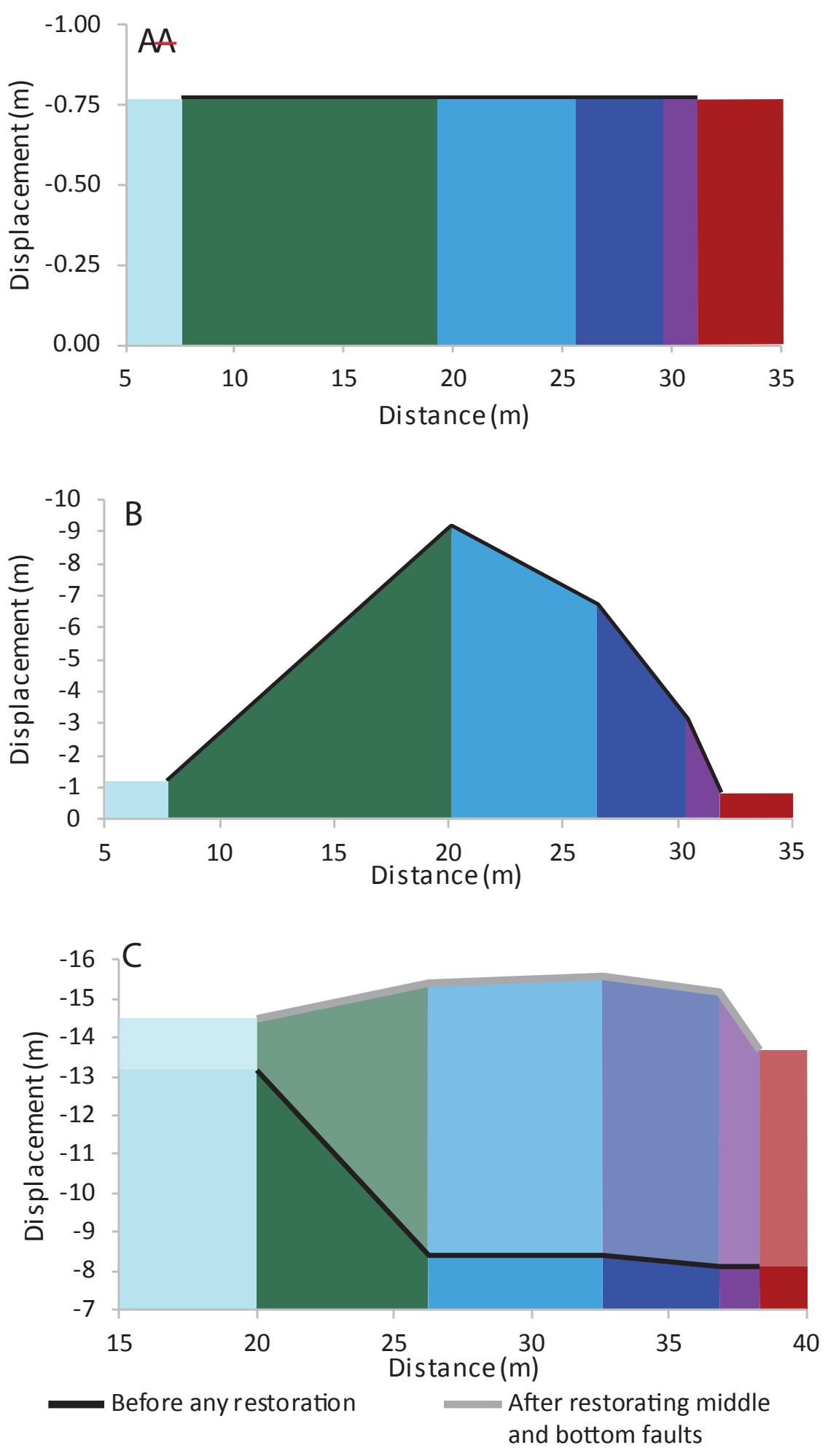

Figure 6 Wigginton et al., 2021 preprint 22 July 2021 


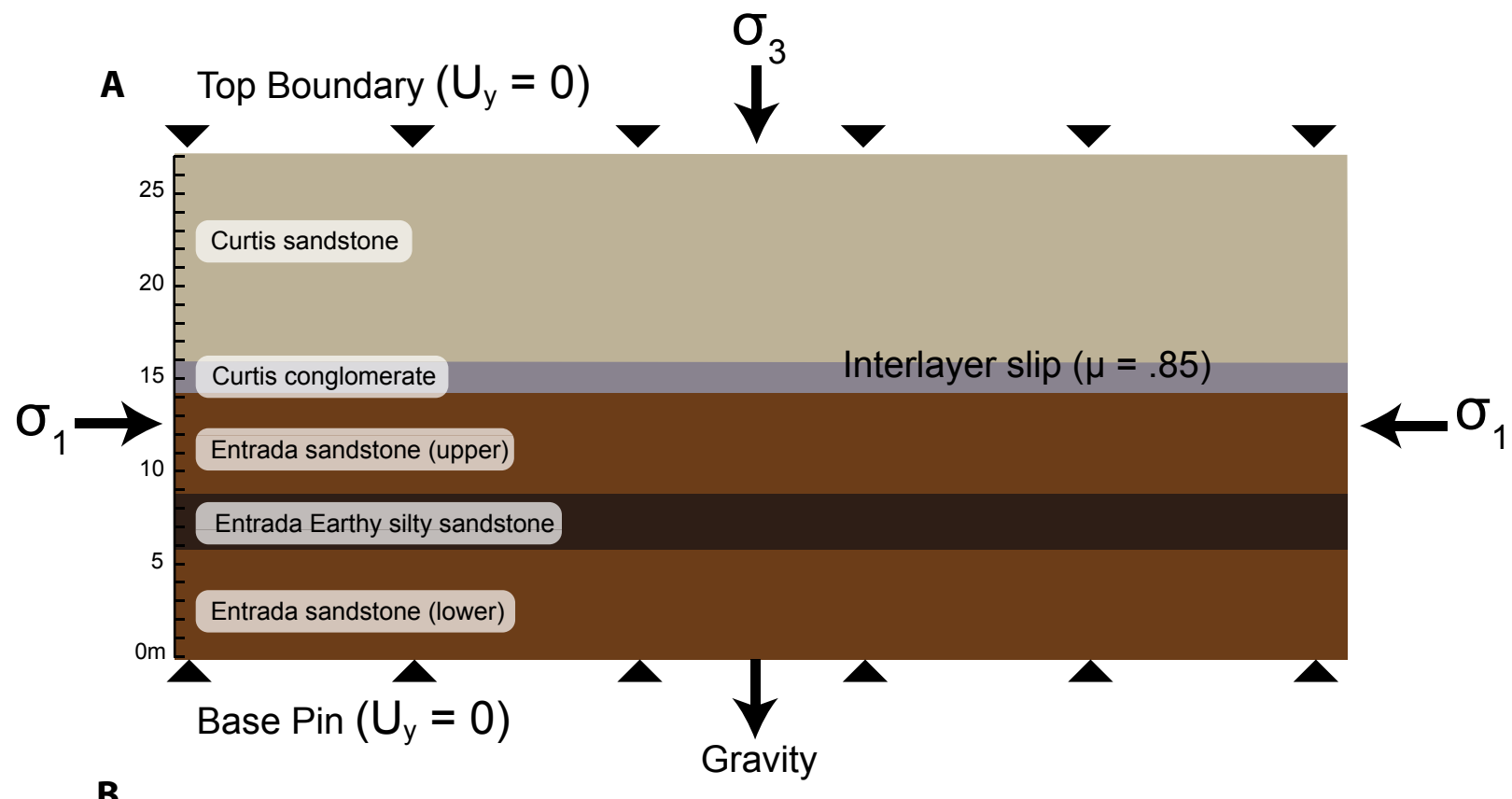

B

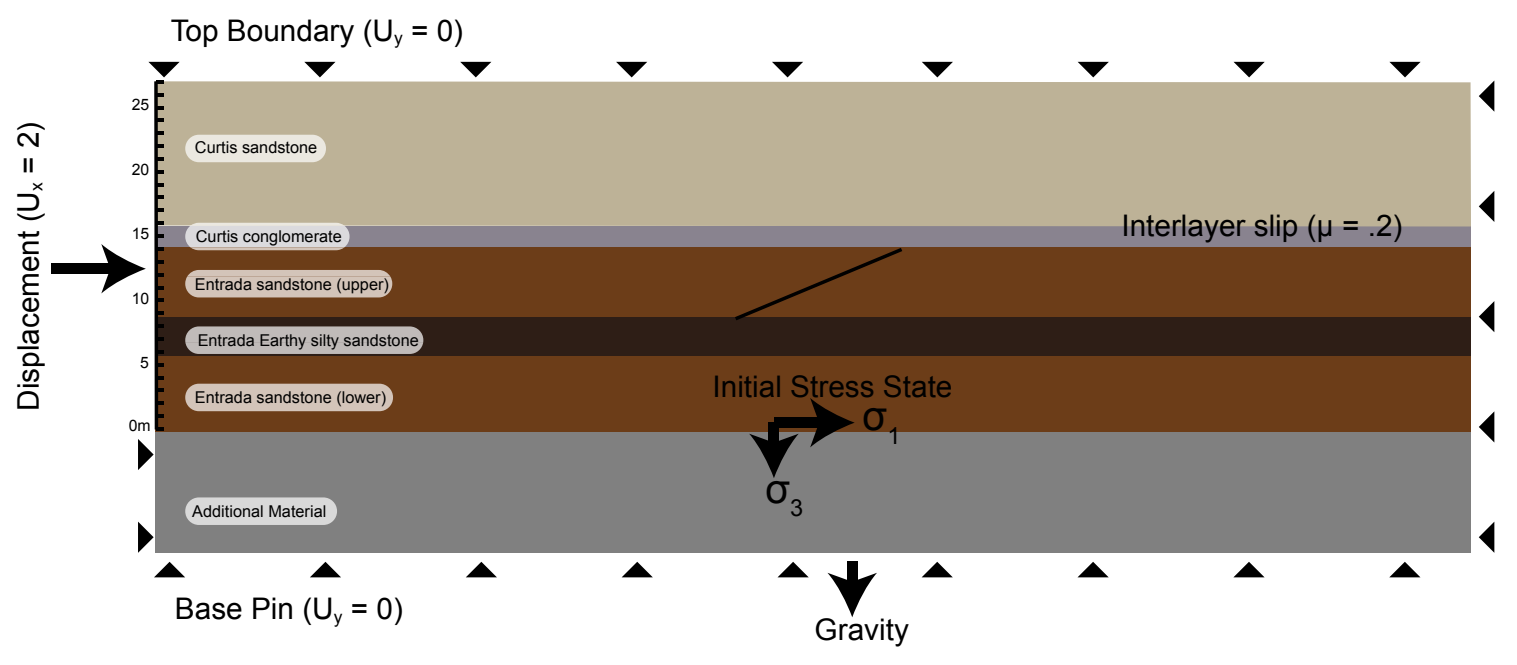

Figure 7. Wigginton et al., 2021 preprint 22 July 2021 

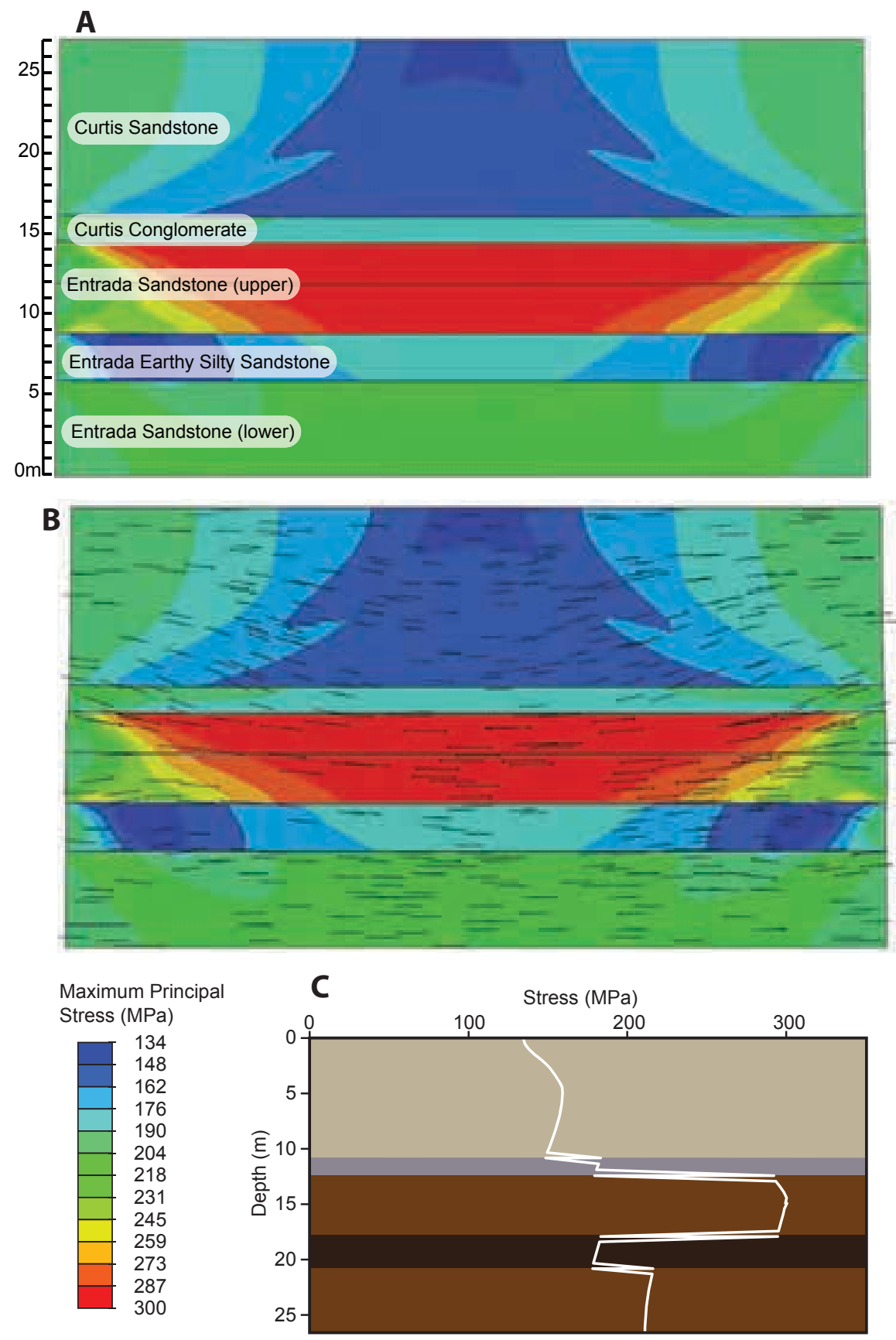

Figure 8. Wigginton et al., 2021 preprint 22 July 2021 

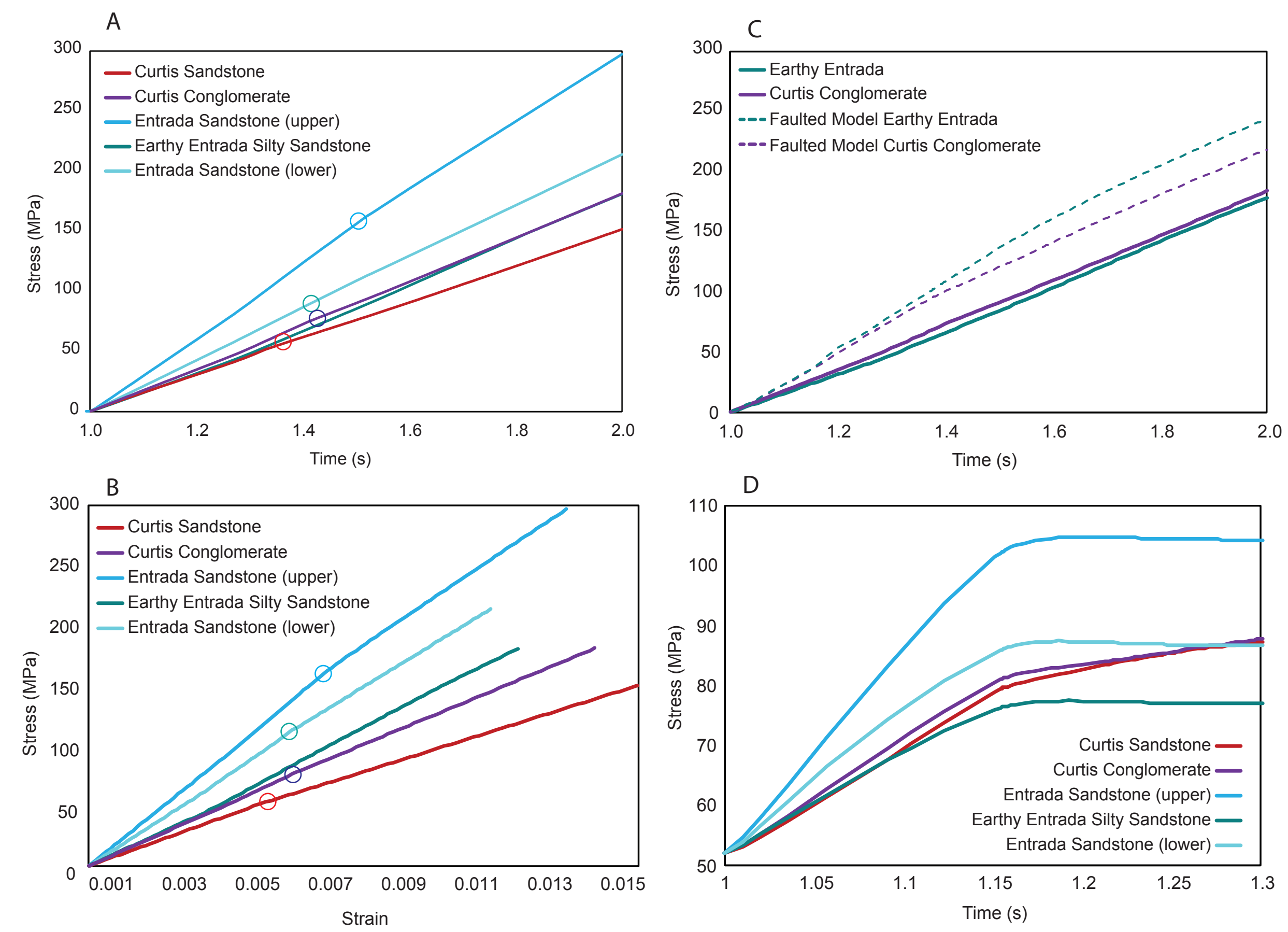

Figure 9. Wigginton et al., 2021 preprint 22 July 2021 
A

$\boldsymbol{\mu}=\mathbf{0 . 0}$

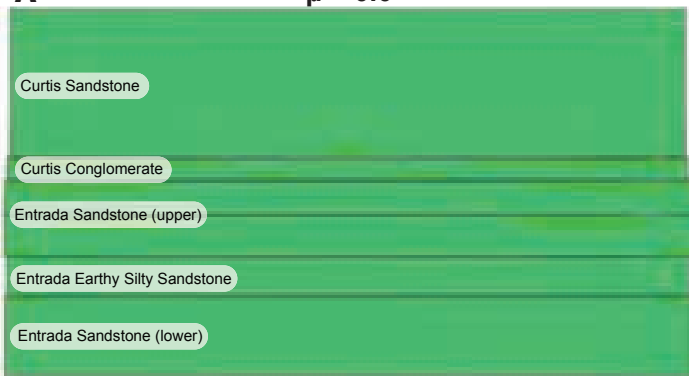

C

$\mu=0.4$

Curtis Sandstone

\section{Curtis Conglomerate}

Entrada Sandstone (upper)

Entra Sandsto (upper

Entrada Earthy Silty Sandstone

Entrada Sandstone (lower)
B $\quad \mu=0.2$

Curtis Sandstone

Curtis Conglomerate

Entrada Sandstone (upper)

Entrada Earthy Silty Sandstone

Entrada Sandstone (lower)

D $\quad \mu=0.85$

Curtis Sandstone

Curtis Conglomerate

Entrada Sandstone (upper)

Entrada Earthy Silty Sandstone

Entrada Sandstone (lower)

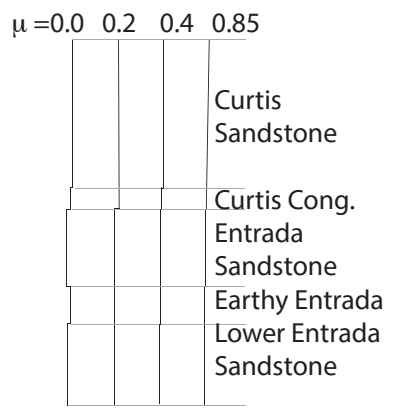

Figure 10. Wigginton et al., 2021 preprint 22 July 2021 


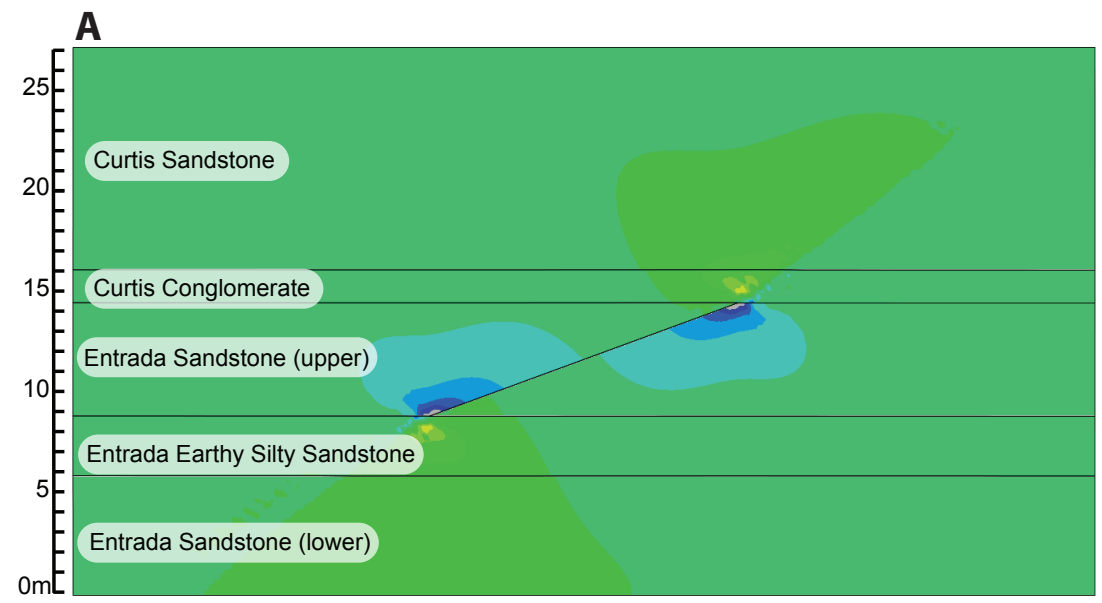

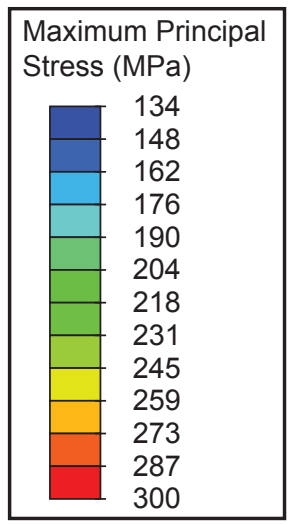

B

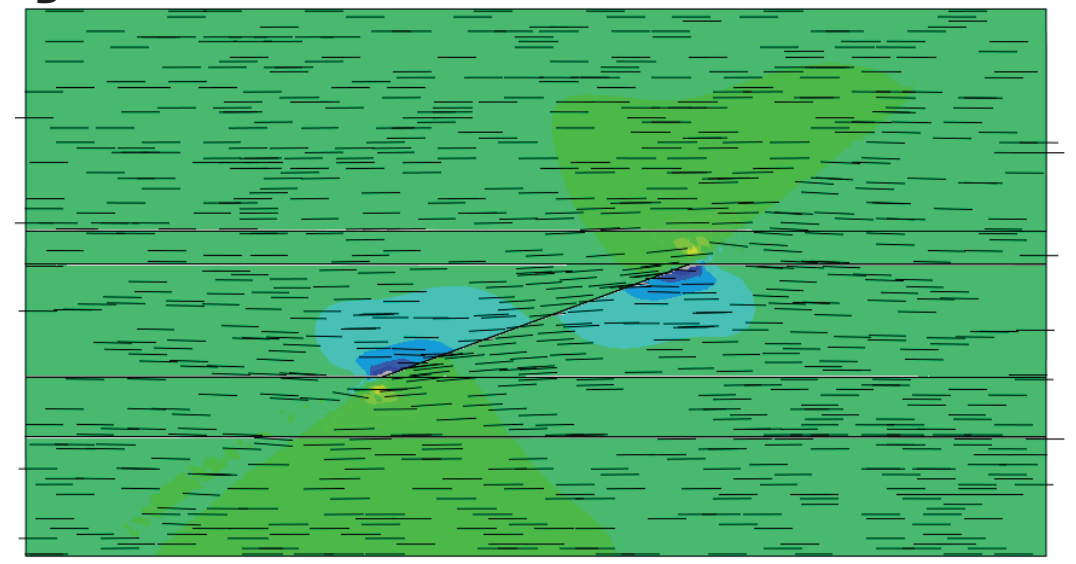

Figure 11. Wigginton et al., 2021 preprint 22 July 2021 


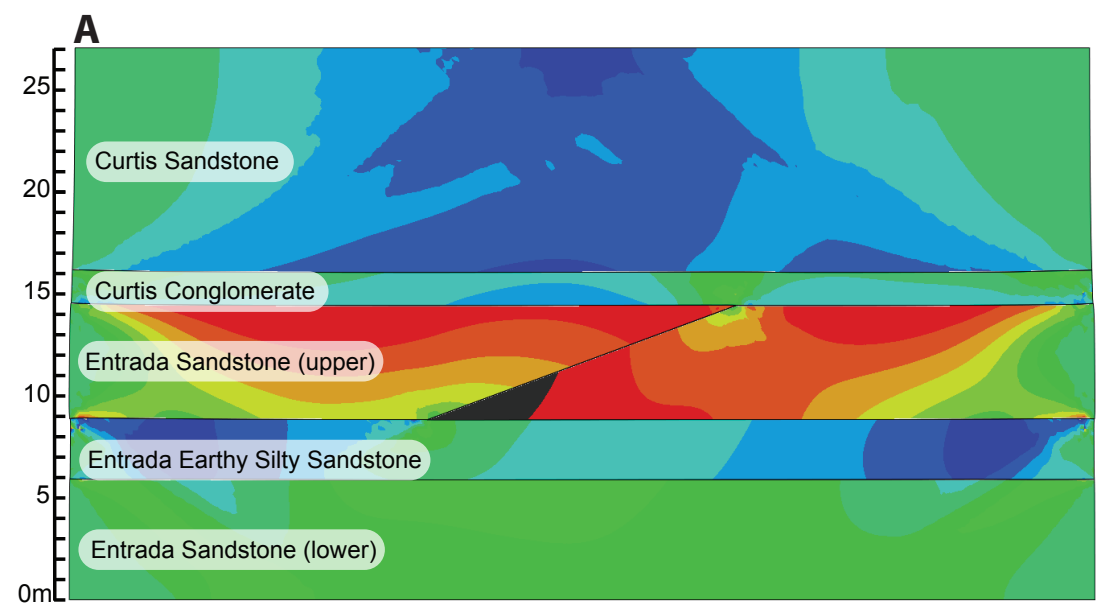

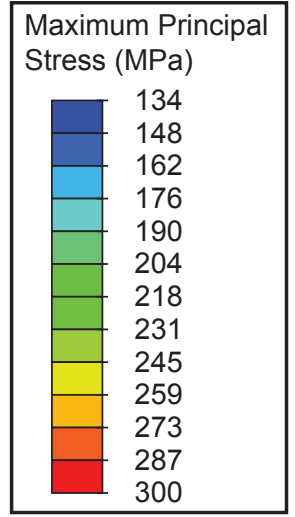

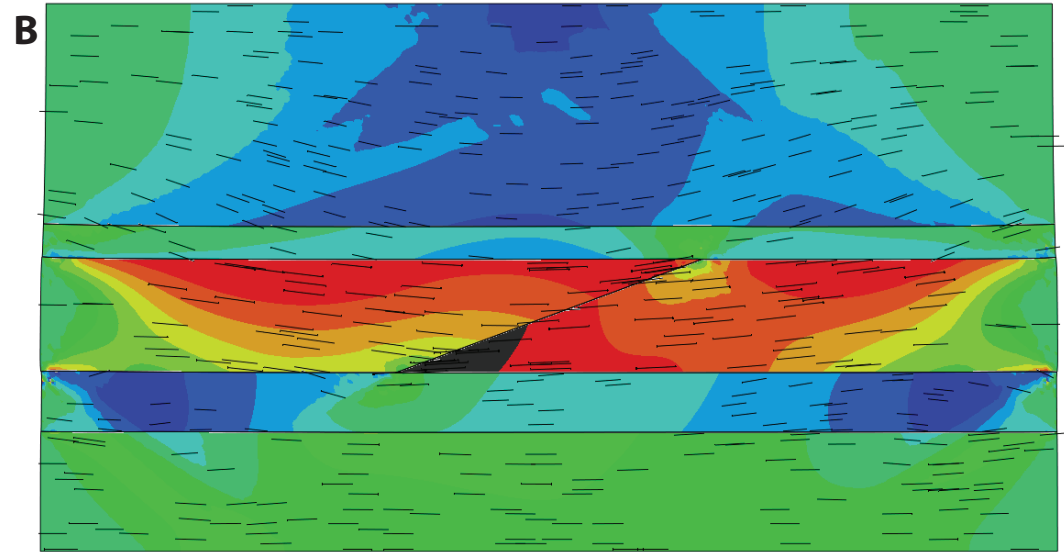

Figure 12. Wigginton et al., 2021 preprint 22 July 2021 

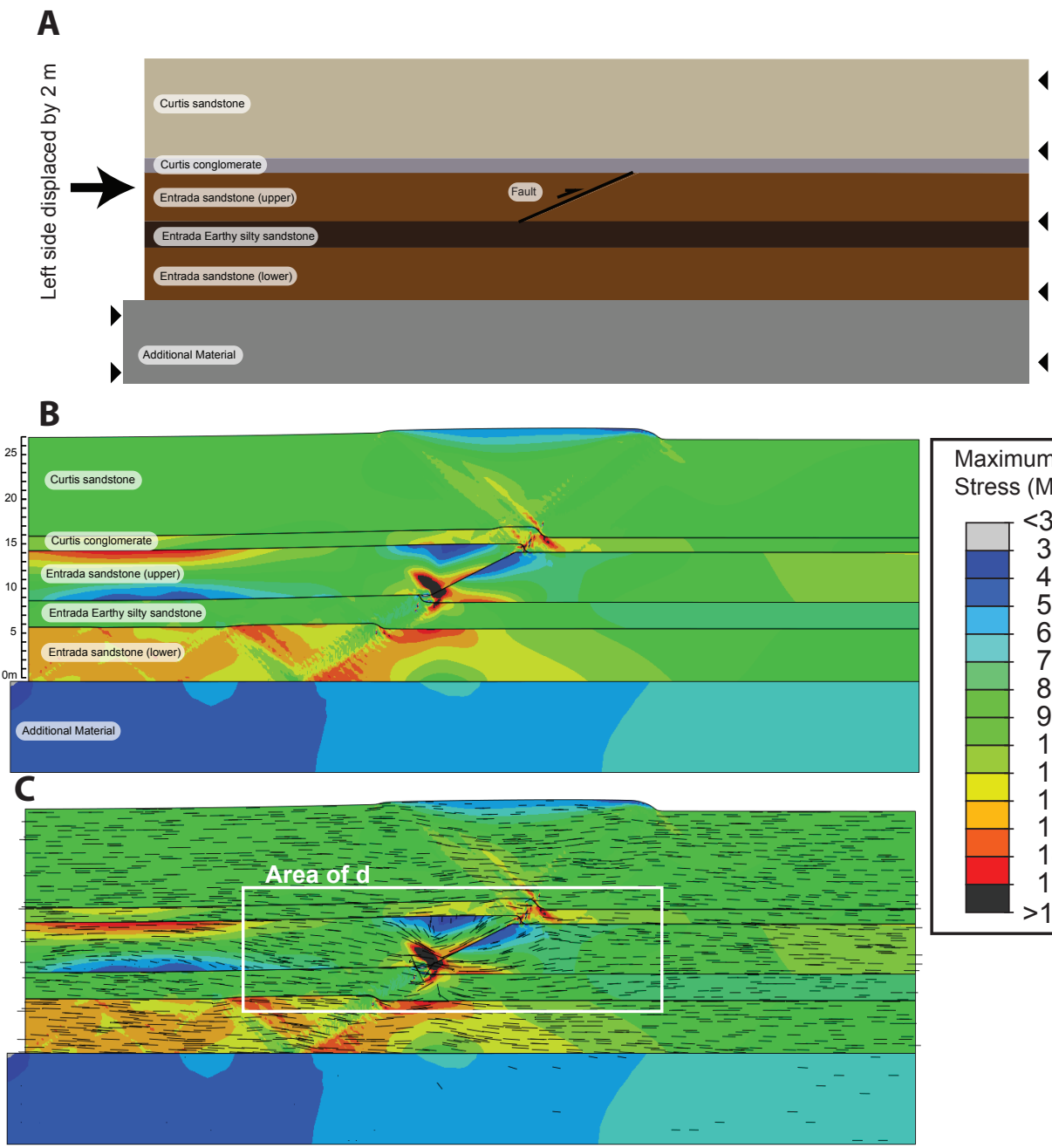

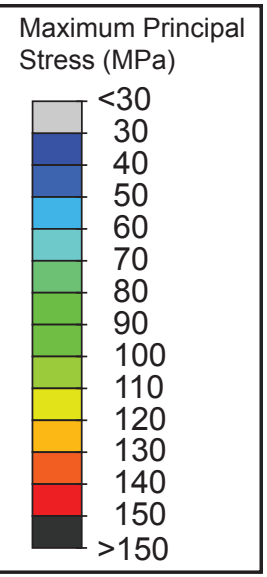

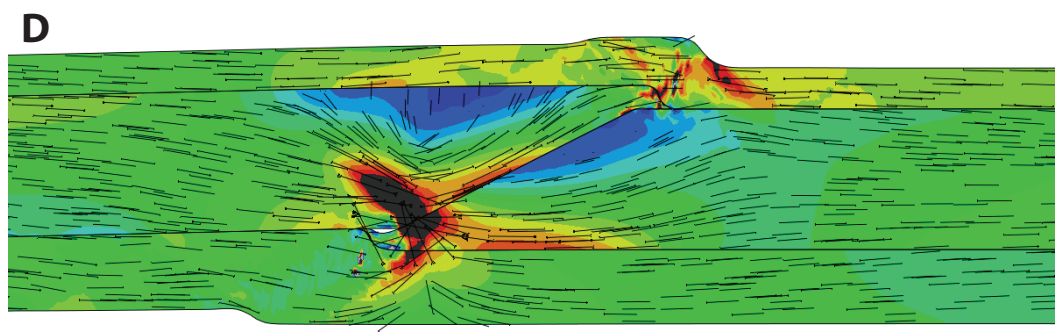

Figure 13. Wigginton et al., 2021 preprint 22 July 2021 

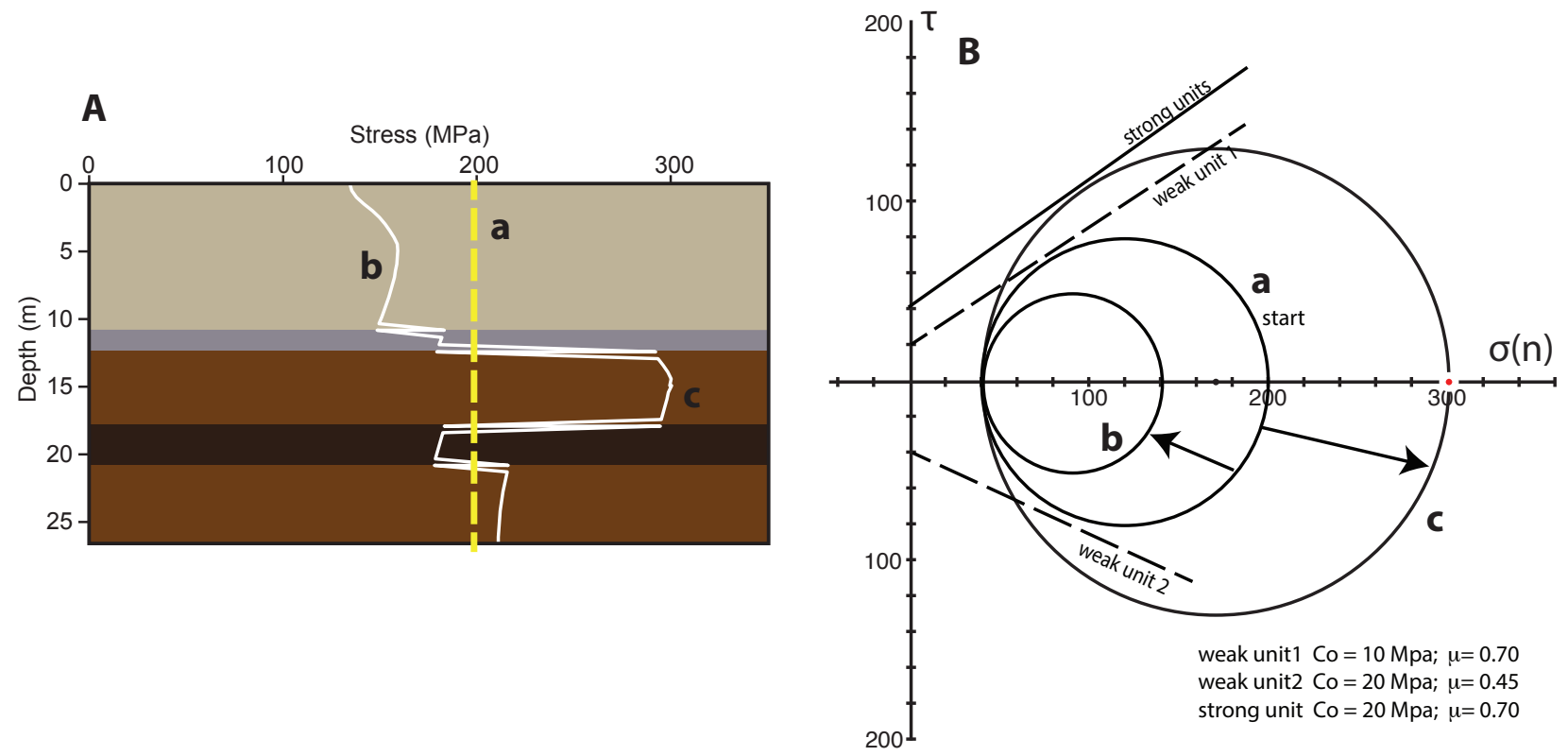

Figure 14. Wigginton et al., 2021 preprint 22 July 2021 